\title{
КОРРЕЛЯЦИЯ ПРОЦЕССОВ РУДООБРАЗОВАНИЯ НА ЗОЛОТО-ПОЛИМЕТАЛЛИЧЕСКОМ МЕСТОРОЖДЕНИИ БЕРЕЗИТОВОЕ ЗАПАДНОЙ ЧАСТИ СЕЛЕНГИНО-СТАНОВОГО СУПЕРТЕРРЕЙНА И РЕГИОНАЛЬНЫХ ТЕКТОНОМАГМАТИЧЕСКИХ СОБЫТИЙ
}

\author{
А.А. Сорокин, В.А. Пономарчук*, А.В. Травин*, Л.И. Рогулина, А.В. Пономарчук* \\ Институт геологии и природопользования ДВО РАН, 675000, Благовещенск, пер. Рёлочный, 1, Россия \\ * Институт геологии и минералогии им. В.С. Соболева СО РАН, 630090, Новосибирск, просп. Академика Коптюга, 3 , Россия
}

\begin{abstract}
В результате проведенных исследований $\left({ }^{40} \mathrm{Ar} /{ }^{39} \mathrm{Ar}\right.$ метод) установлен возраст ряда ключевых магматических комплексов западной части Селенгино-Станового супертеррейна: трахиандезибазальты куйтунского (чичаткинского) комплекса - 259.4 6.2 млн лет; габбро тукурингрского комплекса $156.3 \pm 4.8$ млн лет; граниты и пегматиты тукурингрского комплекса $-153.1 \pm 3.8,154.0 \pm 4.4,156.8 \pm 4.0$,

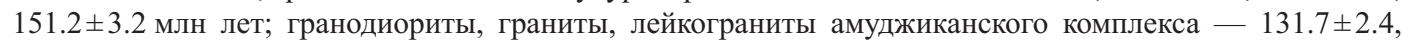
$134.5 \pm 2.8,131.6 \pm 4.2$ млн лет; дайки лампрофиров - 125.2 $\pm 2.4,125.2 \pm 3.4$ млн лет. Выявлены два этапа гидротермального рудного процесса с возрастом 132-131 и 125 млн лет. Показано, что формирование месторождения, проявление наложенных процессов отвечают общим закономерностям позднемезозойской истории тихоокеанской окраины Азии.
\end{abstract}

Геодинамика, граниты, мезозой, месторождение Березитовое, Селенгино-Становой супертеррейн.

\section{CORRELATION BETWEEN THE ORE FORMATION PROCESSES IN THE BEREZITOVOE GOLD-COMPLEX-METAL DEPOSIT (western part of the Selenga-Stanovoy superterrane) AND THE REGIONAL TECTONOMAGMATIC EVENTS}

\begin{abstract}
A.A. Sorokin, V.A. Ponomarchuk, A.V. Travin, L.I. Rogulina, A.V. Ponomarchuk
The age of the major igneous complexes in the western part of the Selenga-Stanovoy superterrane has been estimated by ${ }^{40} \mathrm{Ar} /{ }^{39} \mathrm{Ar}$ dating: trachyandesite-basalts of the Kuitun (Chichatka) complex $-259.4 \pm 6.2 \mathrm{Ma}$; gabbro of the Tukuringra complex $-156.3 \pm 4.8 \mathrm{Ma}$; granites and pegmatites of the Tukuringra complex $153.1 \pm 3.8,154.0 \pm 4.4,156.8 \pm 4.0$, and 151.2 $\pm 3.2 \mathrm{Ma}$; granodiorites, granites, and leucogranites of the Amudzhikan complex - 131.7 $\pm 2.4,134.5 \pm 2.8$, and $131.6 \pm 4.2 \mathrm{Ma}$; and lamprophyre dikes $-125.2 \pm 2.4$ and 125.2 $\pm 3.4 \mathrm{Ma}$. Two stages of hydrothermal ore formation process have been recognized: $132-131$ and $\sim 125 \mathrm{Ma}$. It is shown that the deposit formation and superposed processes follow the general regularities of the Late Mesozoic evolution of the Pacific Asia margin.
\end{abstract}

Geodynamics, granites, Mesozoic, Berezitovoe deposit, Selenga-Stanovoy superterrane

\section{ВВЕДЕНИЕ}

Селенгино-Становой супертеррейн [Парфенов и др., 2003] юго-восточной окраины Северо-Азиатского кратона является одной из ключевых структур восточной окраины Азии. Основу его геологического строения составляют традиционно выделяемые условно ранне- и позднедокембрийские комплексы, а также многочисленные интрузивные и вулканоплутонические ассоциации палеозоя и мезозоя.

В результате геохронологических исследований существенно уточнен возраст целого ряда магматических и метаморфических комплексов Селенгино-Станового супертеррейна. В частности, показано, что к раннедокембрийским образованиям относятся гранулиты могочинской серии [Гаврикова и др., 1991], а также габбро-анортозитовые комплексы [Поляков и др., 2006; Бучко и др., 2006, 2008; Попов и др., 2009]. В фанерозойской истории этого террейна выделяются [Ларин и др., 2005, 2010, 2011; Цыганков и др., 2010; Донская и др., 2012; Бучко и др., 2012б] несколько этапов магматической активности, приходящихся на средний палеозой, пермь-триас, среднюю-позднюю юру, ранний мел.

Сложная и многостадийная эволюция тектонических структур, в ходе которой функционировали разновозрастные и разнотипные магматические и рудообразующие системы, обусловленные различными геодинамическими обстановками, привела к формированию не менее сложного металлогенического облика региона. При этом изотопно-геохронологическая изученность большинства рудных объектов вплоть до недавнего времени также оставалась слабой, что затрудняло корреляцию тектонических, магматических и рудообразующих процессов. Однако в последние годы стали проводиться планомерные геохронологические исследования рудных месторождений [Моисеенко и др., 1997, 1999; Берзина, Сотников, 1999, 2011; Сотников и др., 2005, 2007a, 2007б; Прокофьев и др., 2006; Куликова и др., 2007;

(ㄷ) А.А. Сорокин, В.А. Пономарчук, А.В. Травин, Л.И. Рогулина, А.В. Пономарчук, 2014 
Сорокин и др., 2008, 2011; Мельников и др., 2009; Бучко и др., 2010, 2012а; Добрецов, Буслов, 2011] на основе современных аналитических методик, результаты которых позволяют увязать рудный процесс с теми или иными магматическими комплексами. В то же время итоги этих исследований (в том числе и полученные ранее данные для Березитового месторождения [Сорокин и др., 2008; Мельников и др., 2009]) в большинстве случаев носят точечный характер, подразумевающий изотопное датирование единичных образцов гидротермально-метасоматических образований. Такой подход, безусловно, дает информацию о возрасте главного этапа рудоотложения, но не позволяет проследить всю хронологию формирования месторождения, что особенно важно в случае многоэтапности этого процесса, увязать ее с региональными тектономагматическими событиями. Указанная проблема может быть решена только при целенаправленном исследовании как гидротермальных рудных, так и вмещающих метаморфических и магматических пород, что и предлагается рассмотреть в данной работе на примере Березитового золото-полиметаллического месторождения.

\section{ГЕОЛОГИЧЕСКАЯ ПОЗИЦИЯ МЕСТОРОЖДЕНИЯ}

Месторождение Березитовое расположено в пределах восточной части Селенгино-Станового супертеррейна в бассейне верховьев р. Ольдой (рис. 1, 2). Наиболее древними образованиями в пределах рудного поля являются условно раннедокембрийские метаморфические комплексы могочинской серии

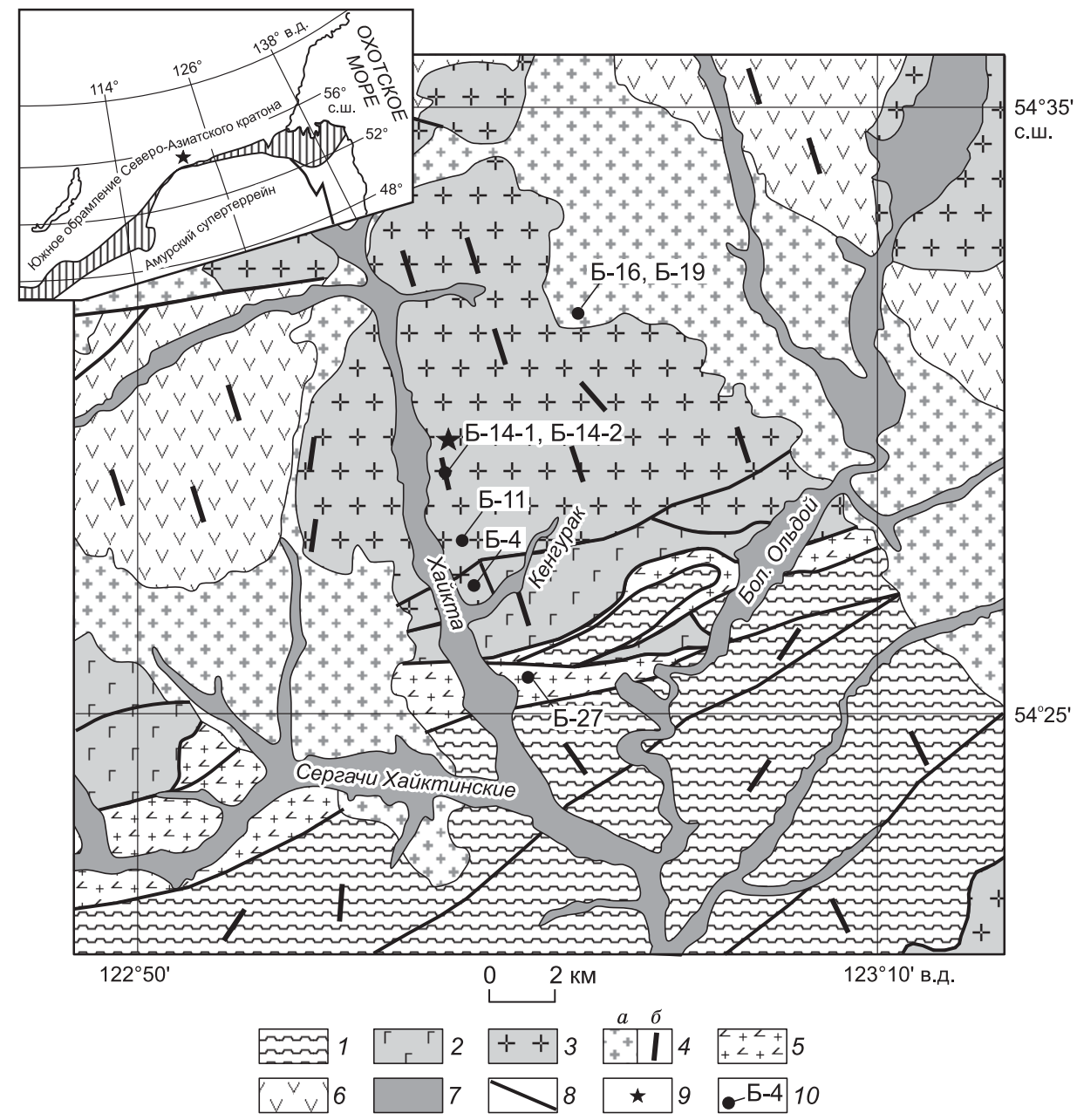

Рис. 1. Положение месторождения Березитовое в основных геологических структурах региона, по [Козак, Вахтомин, 2000а,б; Эйриш, 2002] с изменениями авторов.

1 - условно раннедокембрийские метаморфические комплексы могочинской серии; 2 - раннепротерозойские габбро, габброанортозиты; 3 - гнейсовидные габбро, гранитоиды тукурингрского комплекса раннепротерозойского, по [Вольский, 1979; Козак, Вахтомин, 2000а,б], или мезозойского, по [Ларин и др., 2005, 2010], возраста; 4 - позднеюрские граниты, гранодиориты $(a)$ и дайки лейкогранитов (б) амуджиканского комплекса; 5 - позднепермские трахиандезиты куйтунского (чичаткинского) комплекса; 6 - позднемезозойские риолиты, трахириолиты; 7 - кайнозойские рыхлые отложения; 8 - разломы; 9 - месторождение Березитовое; 10 - места отбора образцов для геохронологических исследований и их номера. На врезке показано положение месторождения Березитовое. Заштрихованная область - Монголо-Охотский складчатый пояс. 


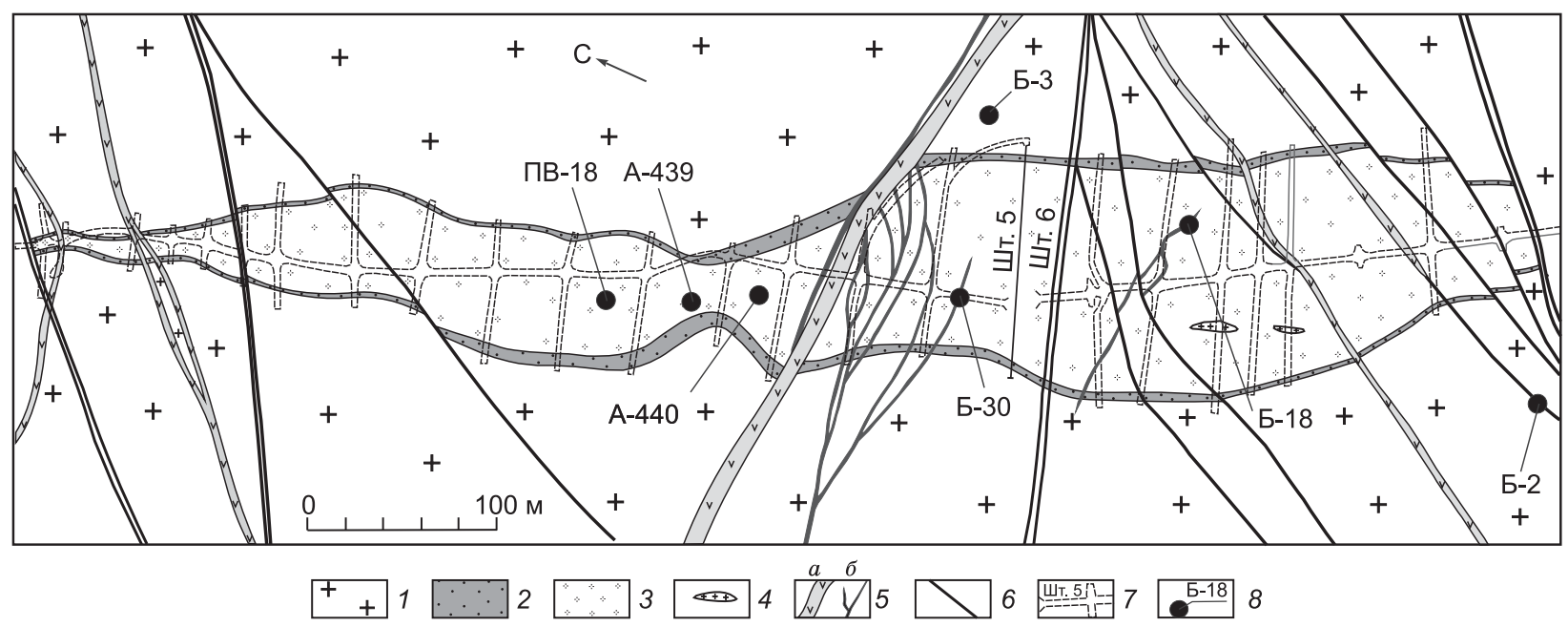

Рис. 2. Схема геологического строения метасоматической зоны № 1 Березитового месторождения на горизонте разведочных штолен 5, 6, по [Вах и др., 2009] с изменениями авторов.

1 - гранитоиды тукурингрского комплекса; 2, 3- рудовмещающие метасоматические породы внешней (2) и внутренней (3) зон; 4 - ксенолиты частично измененных гранитоидов; 5 - дайки: метапорфиритов (a), лампрофиров (б); 6 - основные тектонические нарушения; 7 - разведочные выработки, 8 - места отбора образцов для геохронологических исследований и их номера.

и палеопротерозойские габбро и габбро-анортозиты (см. рис. 1). В рамках существующих схем корреляции магматических комплексов эти образования традиционно относились к раннему архею [Вольский и др., 1979; Мартынюк и др., 1990; Козак, Вахтомин, 2000а,б], однако, согласно полученным данным, возраст гранулитового метаморфизма могочинской серии составляет $1873 \pm 8$ млн лет [Гаврикова и др., 1991], а габбро-анортозитов - $1866 \pm 6$ млн лет [Бучко и др., 2006, 2008].

Рудные тела локализованы в гранитоидах, относимых к тукурингрскому комплексу [Вольский и др., 1979], возраст которых дискуссионен. В легендах геологических карт эти образования традиционно относятся к раннему протерозою [Вольский и др., 1979; Мартынюк и др., 1990; Козак, Вахтомин, $2000 \mathrm{a}, б]$, хотя результаты геохронологических исследований (U-Pb метод по цирконам) указывают на мезозойский возраст [Ларин и др., 2005, 2006, 2010].

В непосредственной близости от месторождения достаточно широко развиты магматические образования, представленные позднепермскими вулканитами кислого состава, относимые к куйтунскому [Вольский и др., 1979] или чичаткинскому [Козак, Вахтомин, 2000а,б] комплексу (см. рис. 1), а также триасовыми гранитоидами нерчуганского комплекса.

Наиболее молодые магматические комплексы в пределах рудного поля представлены небольшими телами и дайками субщелочных порфировидных гранитоидов амуджиканского комплекса (см. рис. 1), для которого приводятся цифры абсолютного возраста в интервале 175-125 млн лет [Мартынюк и др., 1990; Козак, Вахтомин, 2000а,б] и 132-128 млн лет [Ларин и др., 2005].

Само Березитовое месторождение было неоднократно описано в геологической литературе [Вах, 1989; Моисеенко, Эйриш, 1996; Эйриш, 2002; Вах и др., 2009], и мы сочли возможным лишь упомянуть, что оно частично эксплуатировалось с конца 30 -х годов XX в. и исследовалось несколькими поколениями геологов. Рудная зона месторождения представлена гранат-кварц-серицитовыми метасоматитами с золото-полиметаллической минерализацией, окаймленной гранат-кварц-серицит-калишпатовыми метасоматитами в гранитоидах, относимых к тукурингрскому комплексу (см. рис. 2). Она имеет линзовидную в плане форму, мощность от 110 до 10-12 м, простирание ее северо-западное при крутом падении на юго-запад [Эйриш, 2002; Вах и др., 2009].

\section{МЕТОДИКА ИССЛЕДОВАНИЙ}

${ }^{40} \mathrm{Ar} /{ }^{39} \mathrm{Ar}$ изотопно-геохронологические исследования выполнены в ИГМ СО РАН (г. Новосибирск) методом ступенчатого прогрева по методике, опубликованной в работах [Пономарчук и др., 1998; Травин и др., 2009]. Навески образцов совместно с мусковитом МСА-11, используемым в качестве монитора, заворачивали в алюминиевую фольгу, помещали в кварцевую ампулу и после откачки из нее воздуха запаивали. Мусковит MCA-11, подготовленный ВИМС в 1988 г. как стандартный K/Ar образец, был ат- 
тестован в качестве ${ }^{40} \mathrm{Ar} /{ }^{39} \mathrm{Ar}$ монитора с помощью международных стандартных образцов мусковита Bern 4m, биотита LP-6 [Baksi et al., 1999]. В качестве интегрального возраста мусковита MCA-11 принято среднее результатов калибровки, составившее $311.0 \pm 1.5$ млн лет. Ампулы с образцами помещали в алюминиевый пенал, заполненный для защиты от тепловых нейтронов карбидом бора, и облучали в охлаждаемом водой канале научного реактора ВВР-К типа Физико-технического института при Томском политехническом университете. Градиент нейтронного потока не превышал $0.5 \%$ в размере образца. Эксперименты по ступенчатому прогреву проводились в кварцевом реакторе с печью внешнего прогрева. Холостой опыт по определению ${ }^{40} \operatorname{Ar}\left(10\right.$ мин при $\left.1200^{\circ} \mathrm{C}\right)$ не превышал $5 \cdot 10^{-10} \mathrm{Hcm}^{3}$. Очистка аргона производилась с помощью ZrAl SAES геттеров. Изотопный состав аргона измерялся на масс-спектрометре Noble gas 5400 фирмы Микромасс (Англия). Ошибки измерений соответствуют интервалу $\pm 2 \sigma$. Для коррекции на мешающие изотопы аргона, образовавшиеся во время облучения на Са, К, использовались следующие коэффициенты: $\left({ }^{39} \mathrm{Ar} /{ }^{37} \mathrm{Ar}\right)_{\mathrm{Ca}}=0.00083 \pm 0.000005,\left({ }^{36} \mathrm{Ar} /{ }^{37} \mathrm{Ar}\right)_{\mathrm{Ca}}=0.00052 \pm 0.000006$, $\left({ }^{40} \mathrm{Ar} /{ }^{39} \mathrm{Ar}\right)_{\mathrm{K}}=0.089 \pm 0.001$. Особое внимание уделялось контролю фактора изотопной дискриминации с помощью измерения порции очищенного атмосферного аргона. Среднее значение отношения ${ }^{40} \mathrm{Ar} /{ }^{36} \mathrm{Ar}$ на период измерений составило $296.8 \pm 0.5$. Величины температур ступенчатого прогрева выбирались согласно [Berger, York, 1981].

В случаях слабонарушенных или ненарушенных возрастных спектров ступенчатого прогрева для расчета геохронологических датировок использовались критерии, предложенные в работах [Fleck et al., 1977; Gustafson et al., 2001]. Однако на геологических объектах, сформировавшихся в полихронных обстановках, возрастные ступени в спектрах часто дискордантны, что обусловлено частичной перекристаллизацией и нарушением во фрагментах минералов сохранности накопившегося аргона в результате последующих деформационных и/или термических процессов. В этих случаях возрастная оценка событий в геолого-геохронологическом аспекте проводилась с учетом альтернативных подходов, которые сводятся к следующему: 1) использование для оценки возраста магматизма высокотемпературной ступени в спектре плагиоклаза [Wasserburg, 1987] и других минералах [Baksi, 1999; Segev, 2000]; 2) проведение оценки возраста по методу асимптот и ограничений [Chikov et al., 2002; Forster, Lister, 2004], которое особенно эффективно в случаях смешения аргоновых «парциальных резервуаров» в минерале.

Датировки, полученные с помощью приведенных выше подходов, использовались в геолого-геохронологической интерпретации только в тех случаях, когда аналогичные значения устанавливались по другим образцам, подтверждались датировками, полученными другими методами, и не находились в противоречии с геологическими данными.

\section{РЕЗУЛЬТАТЫ ГЕОХРОНОЛОГИЧЕСКИХ ИССЛЕДОВАНИЙ}

В рамках настоящих исследований выполнено ${ }^{40} \mathrm{Ar} /{ }^{39} \mathrm{Ar}$ геохронологическое датирование для большинства магматических и рудных образований, представленных как в непосредственной близости от месторождения, так и в пределах рудного поля. Эти результаты приведены в табл. $1-3$, на рис. 3,4 , места отбора образцов показаны на рис. 1, 2.

Наиболее древние датировки получены нами для роговой обманки, извлеченной из трахиандезибазальтов (обр. Б-27), образующих выход в нижнем течении р. Хайкта (см. рис. 1). В связи с малым содержанием калия, по экспериментальным данным (см. табл. 1, 2; рис. 3) оказалось, что почти 90 \% выделенного ${ }^{39} \mathrm{Ar}$ распределилось поровну между средне- и высокотемпературной ступенями с соответствующими датировками $211 \pm 4.4$ и $259.4 \pm 6.2$ млн лет. Последнее значение, учитывая довольно значительную долю выделенного ${ }^{39} \mathrm{Ar}$, можно принять в качестве нижней оценки возраста исследованных вулканитов. Низкотемпературные ступени $211.0 \pm 4.8$ и $124.2 \pm 8.8$ млн лет $\left(10 \%\right.$ выделенного $\left.{ }^{39} \mathrm{Ar}\right)$ лет (см. табл. 1, 2; рис. 3) связываются нами с этапами наложенных процессов.

Следующие (в хронологическом порядке) значения возрастов получены нами для гнейсовидных пород, относимых к тукурингрскому комплексу, которые образуют значительный массив площадью око-

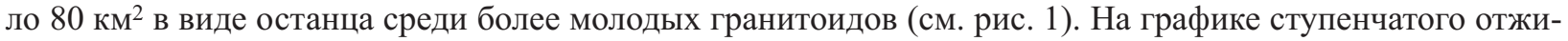
га роговой обманки из гнейсовидного габбро (обр. Б-4), формирующего небольшой выход в приустьевой части руч. Кенгурак (см. рис. 1), в среднетемпературной части спектра выделяются плато с возрастом $128.7 \pm 7.8$ млн лет $\left(47 \%\right.$ выделенного $\left.{ }^{39} \mathrm{Ar}\right)$ и широкая высокотемпературная ступень с возрастом $156.3 \pm 4.8$ млн лет $\left(46 \%\right.$ выделенного ${ }^{39} \mathrm{Ar}$ ) (см. рис. 3 ; табл. 1,2$)$. Основываясь на результатах исследований [Cheilletz et al., 1999; Alexandrov et al., 2002], показавших тесную корреляционную связь формы графика ступенчатого отжига с деформационным воздействием, влиянием низкотемпературных растворов и частичной перекристаллизации на минералы, значение $128.7 \pm 7.8$ млн лет для амфибола из обр. Б-4 интерпретируется как максимальный возраст наложенного процесса, а значение $156.3 \pm 4.8$ млн лет как минимальный возраст образования минерала.

Более сложные результаты получены для гнейсовидных гранитов тукурингрского комплекса (обр. Б-11) из южной части упомянутого выше массива. Аргонограмма для плагиоклаза имеет хорошо 


\begin{tabular}{|c|c|c|c|c|c|c|c|}
\hline $\begin{array}{c}\text { Номер } \\
\text { ступени }\end{array}$ & $\begin{array}{l}\text { Темпера- } \\
\text { тура, }{ }^{\circ} \mathrm{C}\end{array}$ & $\begin{array}{c}\text { Возраст, } \\
\text { млн лет }\end{array}$ & ${ }^{40} \mathrm{Ar} /{ }^{39} \mathrm{Ar}$ & ${ }^{38} \mathrm{Ar} /{ }^{39} \mathrm{Ar}$ & ${ }^{37} \mathrm{Ar} /{ }^{39} \mathrm{Ar}$ & ${ }^{36} \mathrm{Ar} /{ }^{39} \mathrm{Ar}$ & $\begin{array}{c}\text { Доля выделен- } \\
\text { ного }{ }^{39} \mathrm{Ar}, \%\end{array}$ \\
\hline \multicolumn{8}{|c|}{ Обр. Б-27, роговая обманка $(\mathrm{J}=0.004065 \pm 0.000043)$} \\
\hline 1 & 600 & $310.0 \pm 73.0$ & $69.6 \pm 2.2$ & $0.028 \pm 0.036$ & $1.61 \pm 0.28$ & $0.081 \pm 0.038$ & 1.4 \\
\hline 2 & 750 & $123.0 \pm 20.8$ & $27.1 \pm 0.4$ & $0.027 \pm 0.004$ & $0.968 \pm 0.094$ & $0.033 \pm 0.010$ & 6.9 \\
\hline 3 & 900 & $127.4 \pm 32.3$ & $31.7 \pm 0.4$ & $0.046 \pm 0.016$ & $2.96 \pm 0.098$ & $0.046 \pm 0.016$ & 11.6 \\
\hline 4 & 1030 & $211.0 \pm 4.8$ & $31.7 \pm 0.2$ & $0.029 \pm 0.002$ & $12.4 \pm 0.2$ & $0.0041 \pm 0.0008$ & 55.1 \\
\hline 5 & 1130 & $259.4 \pm 6.2$ & $40.6 \pm 0.2$ & $0.019 \pm 0.002$ & $6.82 \pm 0.02$ & $0.0091 \pm 0.0014$ & 100 \\
\hline \multicolumn{8}{|c|}{ Возраст по всем ступеням $220.1 \pm 5.0$ млн лет } \\
\hline \multicolumn{8}{|c|}{ Обр. Б-4, роговая обманка $(\mathrm{J}=0.003991 \pm 0.000042)$} \\
\hline 1 & 600 & $128.6 \pm 74.6$ & $92.3 \pm 3.6$ & $0.082 \pm 0.032$ & $1.78 \pm 0.36$ & $0.250 \pm 0.038$ & 2.9 \\
\hline 2 & 800 & $127.0 \pm 7.8$ & $24.1 \pm 0.2$ & $0.025 \pm 0.004$ & $0.831 \pm 0.042$ & $0.020 \pm 0.004$ & 24.3 \\
\hline 3 & 900 & $130.4 \pm 16.8$ & $25.1 \pm 0.2$ & $0.016 \pm 0.008$ & $0.844 \pm 0.058$ & $0.021 \pm 0.008$ & 35.4 \\
\hline 4 & 1000 & $130.4 \pm 8.6$ & $23.4 \pm 0.2$ & $0.021 \pm 0.002$ & $1.491 \pm 0.048$ & $0.015 \pm 0.004$ & 53.6 \\
\hline 5 & 1130 & $156.3 \pm 4.8$ & $25.5 \pm 0.2$ & $0.020 \pm 0.002$ & $4.069 \pm 0.024$ & $0.010 \pm 0.002$ & 100 \\
\hline \multicolumn{8}{|c|}{ Возраст по всем ступеням $141.7 \pm 4.8$ млн лет } \\
\hline \multicolumn{8}{|c|}{ Обр. Б-11, плагиоклаз (J = 0.004998 \pm 0.000065$)$} \\
\hline 1 & 500 & $353.6 \pm 24.2$ & $75.4 \pm 1.2$ & $0.037 \pm 0.010$ & $1.73 \pm 0.42$ & $0.109 \pm 0.010$ & 2.1 \\
\hline 2 & 600 & $138.1 \pm 11.6$ & $30.7 \pm 0.2$ & $0.031 \pm 0.006$ & $1.53 \pm 0.14$ & $0.050 \pm 0.004$ & 8.5 \\
\hline 3 & 700 & $130.3 \pm 5.6$ & $20.6 \pm 0.2$ & $0.023 \pm 0.002$ & $1.34 \pm 0.06$ & $0.019 \pm 0.002$ & 20.3 \\
\hline 4 & 800 & $120.6 \pm 4.4$ & $18.5 \pm 0.2$ & $0.020 \pm 0.002$ & $1.31 \pm 0.06$ & $0.016 \pm 0.002$ & 32.9 \\
\hline 5 & 900 & $116.6 \pm 5.2$ & $19.1 \pm 0.2$ & $0.021 \pm 0.002$ & $0.981 \pm 0.036$ & $0.019 \pm 0.002$ & 46.4 \\
\hline 6 & 1000 & $132.6 \pm 7.2$ & $20.0 \pm 0.2$ & $0.021 \pm 0.002$ & $0.604 \pm 0.088$ & $0.016 \pm 0.002$ & 60.5 \\
\hline 7 & 1130 & $154.0 \pm 4.4$ & $23.7 \pm 0.2$ & $0.020 \pm 0.002$ & $0.620 \pm 0.018$ & $0.020 \pm 0.002$ & 100 \\
\hline
\end{tabular}

Обр. Б-11, роговая обманка-1 $(\mathrm{J}=\mathbf{0 . 0 0 4 0 3 1} \pm \mathbf{0 . 0 0 0 0 4 1})$

\begin{tabular}{l|c|c|}
1 & 500 & $47.9 \pm 20.6$ \\
2 & 600 & $108.4 \pm 5.6$ \\
3 & 700 & $118.4 \pm 3.4$ \\
4 & 800 & $114.3 \pm 3.4$ \\
5 & 900 & $119.6 \pm 3.4$ \\
6 & 1000 & $119.4 \pm 3.2$ \\
7 & 1070 & $119.8 \pm 4.0$ \\
8 & 1130 & $114.7 \pm 4.2$
\end{tabular}

\begin{tabular}{|l|l|}
$14.2 \pm 0.2$ & $0.017 \pm 0.006$ \\
$16.7 \pm 0.2$ & $0.019 \pm 0.004$ \\
$15.6 \pm 0.2$ & $0.017 \pm 0.002$ \\
$15.5 \pm 0.2$ & $0.001 \pm 0.002$ \\
$16.1 \pm 0.2$ & $0.017 \pm 0.002$ \\
$15.6 \pm 0.2$ & $0.018 \pm 0.002$ \\
$15.9 \pm 0.2$ & $0.021 \pm 0.002$ \\
$17.4 \pm 0.2$ & $0.019 \pm 0.002$
\end{tabular}

$0.547 \pm 0.266$
$0.402 \pm 0.054$
$0.163 \pm 0.016$
$0.326 \pm 0.018$
$0.740 \pm 0.034$
$0.439 \pm 0.010$
$0.777 \pm 0.032$
$2.651 \pm 0.052$

$\left|\begin{array}{l}0.030 \pm 0.008 \\ 0.015 \pm 0.002 \\ 0.007 \pm 0.002 \\ 0.008 \pm 0.002 \\ 0.008 \pm 0.002 \\ 0.007 \pm 0.002 \\ 0.008 \pm 0.002 \\ 0.014 \pm 0.002\end{array}\right|$

1.7

54.0

82.1

95.7 100

Обр. Б-11, роговая обманка-2 $(\mathrm{J}=\mathbf{0 . 0 0 4 9 8 2} \pm \mathbf{0 . 0 0 0 0 5 9})$

\begin{tabular}{l|c|c|}
1 & 500 & $78.0 \pm 63.7$ \\
2 & 600 & $67.3 \pm 14.6$ \\
3 & 750 & $93.1 \pm 7.0$ \\
4 & 900 & $106.6 \pm 9.2$ \\
5 & 1000 & $109.8 \pm 8.0$ \\
6 & 1130 & $112.0 \pm 4.0$
\end{tabular}

\begin{tabular}{l|l}
$34.9 \pm 1.6$ & $0.106 \pm 0.064$ \\
$19.7 \pm 0.2$ & $0.043 \pm 0.010$ \\
$16.1 \pm 0.2$ & $1.770 \pm 0.262$ \\
$20.4 \pm 0.2$ & $0.024 \pm 0.006$ \\
$16.7 \pm 0.2$ & $0.022 \pm 0.002$ \\
$16.5 \pm 0.2$ & $0.017 \pm 0.002$
\end{tabular}

$8.160 \pm 1.262$
$1.091 \pm 0.099$
$0.372 \pm 0.056$
$2.161 \pm 0.084$
$0.654 \pm 0.098$
$0.826 \pm 0.062$

$0.088 \pm 0.042$
$0.041 \pm 0.006$
$0.018 \pm 0.002$
$0.028 \pm 0.004$
$0.016 \pm 0.002$
$0.012 \pm 0.002$

1.3

8.9

29.2

40.1

69.8

100

Возраст по всем ступеням $101.8 \pm 4.4$ млн лет

\section{Обр. Б-2, биотит $(\mathrm{J}=\mathbf{0 . 0 0 4 3 0 7} \pm \mathbf{0 . 0 0 0 0 4 9})$}

\begin{tabular}{l|c|c|c|c}
1 & 550 & $52.6 \pm 9.2$ & $25.3 \pm 0.2$ & $0.037 \pm 0.004$ \\
2 & 650 & $90.0 \pm 3.2$ & $24.0 \pm 0.2$ & $0.030 \pm 0.002$ \\
3 & 750 & $111.1 \pm 4.0$ & $23.7 \pm 0.2$ & $0.025 \pm 0.002$ \\
4 & 850 & $112.6 \pm 9.6$ & $30.4 \pm 0.2$ & $0.041 \pm 0.004$ \\
5 & 1000 & $117.3 \pm 4.6$ & $26.1 \pm 0.2$ & $0.027 \pm 0.002$ \\
6 & 1130 & $153.1 \pm 3.8$ & $28.4 \pm 0.2$ & $0.025 \pm 0.002$
\end{tabular}

\begin{tabular}{c|c|c}
$0.012 \pm 0.463$ & $0.063 \pm 0.004$ & 7.9 \\
$0.385 \pm 0.086$ & $0.041 \pm 0.002$ & 25.6 \\
$0.199 \pm 0.173$ & $0.030 \pm 0.002$ & 40.1 \\
$1.18 \pm 0.74$ & $0.052 \pm 0.004$ & 48.7 \\
$0.748 \pm 0.237$ & $0.035 \pm 0.002$ & 74.3 \\
$1.921 \pm 0.178$ & $0.027 \pm 0.002$ & 100
\end{tabular}

Возраст по всем ступеням $115.5 \pm 3.0$ млн лет 
Обр. Б-14-1, роговая обманка $(\mathrm{J}=0.005021 \pm 0.000066)$

\begin{tabular}{l|c|c|}
1 & 500 & $59.9 \pm 21.6$ \\
2 & 600 & $127.5 \pm 16.2$ \\
3 & 700 & $122.5 \pm 6.4$ \\
4 & 800 & $120.0 \pm 4.8$ \\
5 & 900 & $121.2 \pm 8.2$ \\
6 & 1130 & $119.2 \pm 3.8$
\end{tabular}

\begin{tabular}{l|l|}
$13.0 \pm 0.2$ & $0.025 \pm 0.018$ \\
$20.9 \pm 0.2$ & $0.037 \pm 0.004$ \\
$16.4 \pm 0.2$ & $0.014 \pm 0.002$ \\
$17.4 \pm 0.2$ & $0.019 \pm 0.002$ \\
$15.5 \pm 0.2$ & $0.019 \pm 0.004$ \\
$16.6 \pm 0.2$ & $0.017 \pm 0.002$
\end{tabular}

$0.051 \pm 0.091$
$0.236 \pm 0.244$
$0.268 \pm 0.095$
$0.264 \pm 0.058$
$0.242 \pm 0.096$
$0.524 \pm 0.0341$

$0.021 \pm 0.008$
$0.021 \pm 0.006$
$0.008 \pm 0.002$
$0.013 \pm 0.002$
$0.005 \pm 0.002$
$0.010 \pm 0.002$

4.2

11.5

27.4

39.4

56.5

100

Возраст по всем ступеням $118.4 \pm 6.4$ млн лет

Обр. Б-14-1, плагиоклаз $(\mathrm{J}=\mathbf{0 . 0 0 5 0 2 6} \pm \mathbf{0 . 0 0 0 0 6 1})$

\begin{tabular}{l|c|c|}
1 & 500 & $756.0 \pm 19.6$ \\
2 & 600 & $189.2 \pm 5.8$ \\
3 & 700 & $113.9 \pm 3.6$ \\
4 & 800 & $122.2 \pm 3.4$ \\
5 & 900 & $125.0 \pm 3.6$ \\
6 & 1000 & $124.1 \pm 3.8$ \\
7 & 1130 & $156.8 \pm 4.0$
\end{tabular}

\begin{tabular}{c|l}
$145.0 \pm 1.2$ & $0.040 \pm 0.006$ \\
$32.1 \pm 0.2$ & $0.020 \pm 0.002$ \\
$18.0 \pm 0.2$ & $0.018 \pm 0.002$ \\
$15.9 \pm 0.2$ & $0.017 \pm 0.002$ \\
$16.7 \pm 0.2$ & $0.017 \pm 0.002$ \\
$16.4 \pm 0.2$ & $0.017 \pm 0.002$ \\
$21.4 \pm 0.2$ & $0.018 \pm 0.002$
\end{tabular}

$0.915 \pm 0.260$
$0.289 \pm 0.044$
$0.202 \pm 0.022$
$0.157 \pm 0.026$
$0.183 \pm 0.022$
$0.115 \pm 0.028$
$0.138 \pm 0.014$

$0.139 \pm 0.006$
$0.034 \pm 0.002$
$0.017 \pm 0.002$
$0.007 \pm 0.002$
$0.008 \pm 0.002$
$0.008 \pm 0.002$
$0.011 \pm 0.002$

1.9

9.3

24.5

42.4

56.8

69.4

100

Возраст по всем ступеням $151.5 \pm 3.8$ млн лет

Обр. Б-3, полевой шпат $(\mathrm{J}=\mathbf{0 . 0 0 4 3 0 2} \pm \mathbf{0 . 0 0 0 0 4 8})$

\begin{tabular}{l|c|c|}
1 & 500 & $599.0 \pm 13.0$ \\
2 & 600 & $159.9 \pm 3.8$ \\
3 & 700 & $140.1 \pm 3.8$ \\
4 & 775 & $129.1 \pm 3.4$ \\
5 & 850 & $126.3 \pm 4.6$ \\
6 & 925 & $130.0 \pm 3.4$ \\
7 & 1025 & $136.1 \pm 3.6$ \\
8 & 1130 & $151.2 \pm 3.2$
\end{tabular}

\begin{tabular}{l|l}
$112.1 \pm 0.4$ & $0.041 \pm 0.006$ \\
$26.0 \pm 0.2$ & $0.023 \pm 0.002$ \\
$21.8 \pm 0.2$ & $0.020 \pm 0.002$ \\
$18.9 \pm 0.2$ & $0.020 \pm 0.002$ \\
$36.9 \pm 0.2$ & $0.031 \pm 0.002$ \\
$23.4 \pm 0.2$ & $0.023 \pm 0.002$ \\
$23.9 \pm 0.2$ & $0.023 \pm 0.002$ \\
$24.7 \pm 0.2$ & $0.021 \pm 0.002$
\end{tabular}

$0.113 \pm 0.851$
$0.581 \pm 0.218$
$0.155 \pm 0.092$
$0.286 \pm 0.097$
$0.002 \pm 0.072$
$0.223 \pm 0.107$
$0.033 \pm 0.131$
$0.024+0.059$

$0.069 \pm 0.004$
$0.015 \pm 0.002$
$0.010 \pm 0.002$
$0.005 \pm 0.002$
$0.068 \pm 0.002$
$0.020 \pm 0.002$
$0.019 \pm 0.002$
$0.015 \pm 0.002$

2.2

8.8

21.1

31.1

38.2

49.8

62.6

100

Возраст по всем ступеням $153.2 \pm 3.4$ млн лет

Обр. Б-19, роговая обманка $(\mathrm{J}=\mathbf{0 . 0 0 3 8 5 7} \pm \mathbf{0 . 0 0 0 0 4 2})$

\begin{tabular}{c|c|c|}
1 & 600 & $86.0 \pm 5.8$ \\
2 & 700 & $128.4 \pm 3.4$ \\
3 & 800 & $125.6 \pm 3.4$ \\
4 & 900 & $131.4 \pm 3.2$ \\
5 & 1000 & $132.2 \pm 3.0$ \\
6 & 1130 & $131.6 \pm 2.6$
\end{tabular}

$23.8 \pm 0.2$
$23.7 \pm 0.2$
$22.1 \pm 0.2$
$22.5 \pm 0.2$
$24.0 \pm 0.2$
$20.7 \pm 0.2$

$0.025 \pm 0.002$
$0.022 \pm 0.002$
$0.020 \pm 0.002$
$0.022 \pm 0.002$
$0.022 \pm 0.002$
$0.020 \pm 0.002$

$\begin{aligned} 1.12 & \pm 0.02 \\ 0.391 & \pm 0.012 \\ 0.488 & \pm 0.008 \\ 1.02 & \pm 0.02 \\ 2.55 & \pm 0.02 \\ 3.49 & \pm 0.02\end{aligned}$

$0.038 \pm 0.002$
$0.015 \pm 0.002$
$0.012 \pm 0.002$
$0.010 \pm 0.002$
$0.015 \pm 0.002$
$0.003 \pm 0.002$

4.0

12.6

23.9

36.2

51.4

100

Возраст по всем ступеням $128.9 \pm 2.8$ млн лет

Обр. Б-16, роговая обманка $(\mathrm{J}=\mathbf{0 . 0 0 3 9 0 8} \pm \mathbf{0 . 0 0 0 0 4 0})$

\begin{tabular}{l|c|c|}
1 & 500 & $348.4 \pm 90.6$ \\
2 & 600 & $84.8 \pm 34.0$ \\
3 & 700 & $117.9 \pm 30.2$ \\
4 & 800 & $134.8 \pm 6.2$ \\
5 & 900 & $134.1 \pm 7.8$ \\
6 & 1000 & $135.7 \pm 7.4$ \\
7 & 1130 & $134.3 \pm 2.8$
\end{tabular}

\begin{tabular}{|c|}
\hline $139.3 \pm 11.4$ \\
\hline $96.6 \pm 2.2$ \\
\hline $32.8 \pm 0.4$ \\
\hline $22.5 \pm 0.2$ \\
\hline $23.0 \pm 0.2$ \\
\hline $25.3 \pm 0.2$ \\
\hline $21.4 \pm 0.2$ \\
\hline
\end{tabular}

$0.057 \pm 0.092$
$0.073 \pm 0.030$
$0.033 \pm 0.012$
$0.023 \pm 0.004$
$0.021 \pm 0.002$
$0.025 \pm 0.004$
$0.022 \pm 0.002$

$\begin{aligned} 3.27 & \pm 0.94 \\ 1.87 & \pm 0.30 \\ 0.465 & \pm 0.144 \\ 0.108 & \pm 0.018 \\ 0.417 & \pm 0.022 \\ 4.26 & \pm 0.02 \\ 4.19 & \pm 0.02\end{aligned}$

$0.287 \pm 0.084$
$0.285 \pm 0.018$
$0.052 \pm 0.016$
$0.009 \pm 0.002$
$0.011 \pm 0.004$
$0.018 \pm 0.004$
$0.006 \pm 0.002$

0.3

1.7

4.2

14.5

23.1

34.8

100

Возраст по всем ступеням $134.5 \pm 3.0$ млн лет

Обр. Б-16, плагиоклаз $(\mathrm{J}=\mathbf{0 . 0 0 3 9 0 8} \pm \mathbf{0 . 0 0 0 0 4 0})$

\begin{tabular}{l|l|c|}
1 & 500 & $133.6 \pm 24.8$ \\
2 & 600 & $117.4 \pm 10.2$ \\
3 & 700 & $125.1 \pm 7.2$ \\
4 & 800 & $127.2 \pm 9.2$ \\
5 & 900 & $133.4 \pm 5.2$
\end{tabular}

\begin{tabular}{l|l}
$46.9 \pm 0.4$ & $0.042 \pm 0.012$ \\
$23.3 \pm 0.2$ & $0.025 \pm 0.008$ \\
$21.2 \pm 0.2$ & $0.025 \pm 0.004$ \\
$21.7 \pm 0.2$ & $0.023 \pm 0.002$ \\
$22.8 \pm 0.2$ & $0.024 \pm 0.004$
\end{tabular}

$$
\begin{aligned}
0.516 & \pm 0.091 \\
0.679 & \pm 0.098 \\
1.09 & \pm 0.02 \\
1.29 & \pm 0.04 \\
1.21 & \pm 0.04
\end{aligned}
$$

$0.092 \pm 0.012$

3.7

$0.020 \pm 0.004$

10.3

$0.009 \pm 0.004$

$0.010 \pm 0.004$

$0.010 \pm 0.002$

24.0

39.7

54.3 
Окончание табл. 1

\begin{tabular}{|c|c|c|c|c|c|c|c|}
\hline $\begin{array}{l}\text { Номер } \\
\text { ступени }\end{array}$ & $\begin{array}{l}\text { Темпера- } \\
\text { тура, }{ }^{\circ} \mathrm{C}\end{array}$ & $\begin{array}{l}\text { Возраст, } \\
\text { млн лет }\end{array}$ & ${ }^{40} \mathrm{Ar} /{ }^{39} \mathrm{Ar}$ & ${ }^{38} \mathrm{Ar} /{ }^{39} \mathrm{Ar}$ & ${ }^{37} \mathrm{Ar} /{ }^{39} \mathrm{Ar}$ & ${ }^{36} \mathrm{Ar} /{ }^{39} \mathrm{Ar}$ & $\begin{array}{c}\text { Доля выделен- } \\
\text { ного }{ }^{39} \mathrm{Ar}, \%\end{array}$ \\
\hline \multicolumn{8}{|c|}{ Обр. Б-16, плагиоклаз $(\mathrm{J}=0.003908 \pm 0.000040)$} \\
\hline 6 & 1000 & $139.4 \pm 8.8$ & $23.9 \pm 0.2$ & $0.021 \pm 0.004$ & $0.703 \pm 0.044$ & $0.011 \pm 0.004$ & 67.5 \\
\hline 7 & 1130 & $125.4 \pm 3.4$ & $24.1 \pm 0.2$ & $0.023 \pm 0.002$ & $0.265 \pm 0.018$ & $0.019 \pm 0.002$ & 100 \\
\hline \multicolumn{8}{|c|}{ Возраст по всем ступеням $128.5 \pm 3.6$ млн лет } \\
\hline \multicolumn{8}{|c|}{ Обр. Б-14-2, роговая обманка $(\mathrm{J}=0.005045 \pm 0.000066)$} \\
\hline 1 & 500 & $745.6 \pm 27.2$ & $128.3 \pm 1.6$ & $0.043 \pm 0.012$ & $0.119 \pm 0.093$ & $0.091 \pm 0.012$ & 1.5 \\
\hline 2 & 600 & $221.1 \pm 8.6$ & $31.9 \pm 0.2$ & $0.020 \pm 0.004$ & $0.112 \pm 0.050$ & $0.020 \pm 0.002$ & 5.7 \\
\hline 3 & 700 & $164.6 \pm 9.4$ & $21.2 \pm 0.2$ & $0.019 \pm 0.002$ & $0.098 \pm 0.028$ & $0.008 \pm 0.004$ & 15.4 \\
\hline 4 & 800 & $138.9 \pm 5.8$ & $17.8 \pm 0.2$ & $0.018 \pm 0.002$ & $0.127 \pm 0.024$ & $0.007 \pm 0.002$ & 27.9 \\
\hline 5 & 900 & $132.0 \pm 8.2$ & $18.0 \pm 0.2$ & $0.023 \pm 0.002$ & $0.101 \pm 0.026$ & $0.010 \pm 0.002$ & 35.4 \\
\hline 6 & 1000 & $140.5 \pm 8.6$ & $18.8 \pm 0.2$ & $0.020 \pm 0.004$ & $0.068 \pm 0.022$ & $0.009 \pm 0.004$ & 43.4 \\
\hline 7 & 1130 & $184.4 \pm 4.6$ & $24.2 \pm 0.2$ & $0.019 \pm 0.002$ & $0.066 \pm 0.004$ & $0.010 \pm 0.002$ & 100 \\
\hline \multicolumn{8}{|c|}{ Возраст по всем ступеням $117.2 \pm 3.6$ млн лет } \\
\hline \multicolumn{8}{|c|}{ Обр. Б-18, роговая обманка $(\mathrm{J}=0.003969 \pm 0.000042)$} \\
\hline 1 & 500 & $519.8 \pm 92.9$ & $190.4 \pm 18.0$ & $0.189 \pm 0.088$ & $2.14 \pm 0.90$ & $0.357 \pm 0.081$ & 0.9 \\
\hline 2 & 650 & $126.4 \pm 22.4$ & $92.7 \pm 2.0$ & $0.095 \pm 0.022$ & $4.08 \pm 0.22$ & $0.251 \pm 0.012$ & 3.5 \\
\hline 3 & 900 & $160.2 \pm 9.0$ & $32.5 \pm 0.2$ & $0.014 \pm 0.004$ & $1.32 \pm 0.02$ & $0.030 \pm 0.004$ & 21.9 \\
\hline 4 & 960 & $125.7 \pm 10.2$ & $36.1 \pm 0.4$ & $0.025 \pm 0.004$ & $11.7 \pm 0.2$ & $0.060 \pm 0.004$ & 31.0 \\
\hline 5 & 1020 & $126.9 \pm 5.2$ & $23.3 \pm 0.2$ & $0.023 \pm 0.002$ & $7.08 \pm 0.02$ & $0.016 \pm 0.002$ & 66.7 \\
\hline 6 & 1130 & $123.7 \pm 4.8$ & $22.9 \pm 0.2$ & $0.025 \pm 0.002$ & $3.22 \pm 0.02$ & $0.016 \pm 0.002$ & 100 \\
\hline
\end{tabular}

Возраст по всем ступеням $132.0 \pm 3.8$ млн лет

Обр. Б-30, плагиоклаз ( $\mathbf{J}=\mathbf{0 . 0 0 5 0 8 2} \pm 0.000067)$

\begin{tabular}{l|c|c|c|c|c|c|c}
1 & 500 & $143.3 \pm 7.4$ & $23.1 \pm 0.2$ & $0.027 \pm 0.002$ & $2.79 \pm 2.22$ & $0.023 \pm 0.002$ & 4.5 \\
2 & 600 & $122.6 \pm 4.2$ & $15.8 \pm 0.2$ & $0.021 \pm 0.002$ & $1.03 \pm 0.94$ & $0.007 \pm 0.002$ & 21.9 \\
3 & 700 & $121.2 \pm 3.8$ & $15.5 \pm 0.2$ & $0.024 \pm 0.002$ & $2.64 \pm 0.52$ & $0.006 \pm 0.002$ & 41.9 \\
4 & 800 & $121.4 \pm 3.2$ & $15.0 \pm 0.2$ & $0.022 \pm 0.002$ & $1.93 \pm 0.50$ & $0.004 \pm 0.002$ & 61.5 \\
5 & 900 & $124.2 \pm 4.8$ & $15.8 \pm 0.2$ & $0.024 \pm 0.002$ & $4.58 \pm 0.66$ & $0.006 \pm 0.002$ & 70.6 \\
6 & 1000 & $125.4 \pm 4.6$ & $15.9 \pm 0.2$ & $0.022 \pm 0.002$ & $1.90 \pm 0.76$ & $0.006 \pm 0.002$ & 83.6 \\
7 & 1130 & $125.9 \pm 4.0$ & $15.9 \pm 0.2$ & $0.023 \pm 0.002$ & $1.30 \pm 0.80$ & $0.006 \pm 0.002$ & 100
\end{tabular}

Возраст по всем ступеням $124.2 \pm 3.4$ млн лет

Обр. ПВ-18, серицит $(\mathrm{J}=\mathbf{0 . 0 0 4 9 8 1} \pm \mathbf{0 . 0 0 0 0 4 2})$

\begin{tabular}{l|c|c|}
1 & 600 & $105.9 \pm 24.0$ \\
2 & 750 & $125.6 \pm 5.0$ \\
3 & 850 & $125.2 \pm 2.2$ \\
4 & 950 & $125.7 \pm 2.2$ \\
5 & 1030 & $123.3 \pm 3.2$ \\
6 & 1130 & $126.0 \pm 2.2$
\end{tabular}

\begin{tabular}{l|l}
$22.6 \pm 0.2$ & $0.035 \pm 0.012$ \\
$17.5 \pm 0.2$ & $0.020 \pm 0.002$ \\
$15.0 \pm 0.2$ & $0.017 \pm 0.002$ \\
$15.1 \pm 0.2$ & $0.017 \pm 0.002$ \\
$16.2 \pm 0.2$ & $0.021 \pm 0.002$ \\
$14.9 \pm 0.2$ & $0.017 \pm 0.002$
\end{tabular}

$1.86 \pm 0.276$

$0.506 \pm 0.144$

$0.422 \pm 0.018$

$0.290 \pm 0.018$

$0.269 \pm 0.072$

$0.027 \pm 0.028$
0.7

5.7

31.5

57.2

66.8

100

Возраст по всем ступеням $125.4 \pm 3.2$ млн лет

выраженную «седлообразную» форму (см. табл. 1, 2; рис. 3), что с учетом результатов вышеприведенных исследований [Cheilletz et al., 1999; Alexandrov et al., 2002] может быть объяснено влиянием наложенных процессов с участием низкотемпературных флюидов. В таких случаях [Wasserburg, 1987; Forster, Lister, 2004; Rolland et al., 2009] возраст высокотемпературной ступени, которая в данном образце составляет $154.0 \pm 4.4$ млн лет (40 \% выделенного ${ }^{39} \mathrm{Ar}$ ) (см. табл. 1,2 ; рис. 3$)$, отвечает минимальному возрастному пределу закрытия изотопной системы плагиоклаза. В среднетемпературной части аргонограммы плагиоклаза по трем соседним ступеням, образующим малое плато, датировка составила $121.3 \pm 3.0$ млн лет (45 \% выделенного ${ }^{39} \mathrm{Ar}$ ) (см. табл. 1, 2; рис. 3) и интерпретируется как максимальный возрастной предел наложенного процесса. График ступенчатого отжига роговой обманки- 1 , входящей в состав магматической структуры породы этого же образца гнейсовидных гранитов (обр. Б-11), позволяет выделить 


\begin{tabular}{|c|c|c|c|c|c|c|}
\hline \multirow[b]{2}{*}{ Объект, номер образца } & \multicolumn{4}{|c|}{ Экспериментальные данные } & \multicolumn{2}{|c|}{ Интерпретация } \\
\hline & Минерал & $\begin{array}{c}\text { Интеграль- } \\
\text { ный возраст, } \\
\text { млн лет }\end{array}$ & $\begin{array}{l}\text { Возраст по пла- } \\
\text { то, млн лет; ко- } \\
\text { личество выде- } \\
\text { ленного }{ }^{39} \mathrm{Ar}, \%\end{array}$ & $\begin{array}{c}\text { Возраст высоко- } \\
\text { температурной } \\
\text { ступени, млн лет; } \\
\text { количество выде- } \\
\text { ленного }{ }^{39} \mathrm{Ar}, \%\end{array}$ & $\begin{array}{l}\text { Возраст маг- } \\
\text { матического } \\
\text { процесса, } \\
\text { млн лет }\end{array}$ & $\begin{array}{l}\text { Возраст } \\
\text { термально- } \\
\text { го события, } \\
\text { млн лет }\end{array}$ \\
\hline $\begin{array}{l}\text { Трахибазальт куйтунско- } \\
\text { го комплекса, обр. Б-27 }\end{array}$ & Роговая обманка & $220.1 \pm 5.0$ & $211.0 \pm 4.8 ; 45$ & $259.4 \pm 6.2 ; 45$ & $259.4 \pm 6.2$ & $\sim 211, \sim 124$ \\
\hline $\begin{array}{l}\text { Габбро тукурингрского } \\
\text { комплекса, обр. Б-4 }\end{array}$ & $»$ & $141.7 \pm 4.8$ & $128.7 \pm 7.8 ; 47$ & $156.3 \pm 4.8 ; 46$ & $156.3 \pm 4.8$ & $\sim 129$ \\
\hline Гнейсовидный гранит & Роговая обманка-1 & $116.6 \pm 3.0$ & $119.6 \pm 2.2 ; 57$ & - & & $\sim 120$ \\
\hline тукурингрского комплек- & Роговая обманка-2 & $101.8 \pm 4.4$ & $110.8 \pm 4.2 ; 71$ & - & $154.0 \pm 4.4$ & $\sim 111, \sim 93$ \\
\hline са, обр. Б-11 & Плагиоклаз & $142.4 \pm 4.0$ & $121.3 \pm 3.0 ; 45$ & $154.0 \pm 4.4 ; 40$ & & $\sim 121$ \\
\hline $\begin{array}{l}\text { Гнейсовидные граниты } \\
\text { тукурингрского комплек- } \\
\text { ca, обр. Б-2 }\end{array}$ & Биотит & $115.5 \pm 3.0$ & $113.6 \pm 4.0 ; 49$ & $153.1 \pm 3.8 ; 25$ & $153.1 \pm 3.8$ & $\sim 114, \sim 90$ \\
\hline Гнейсовидный гранит & Роговая обманка & $118.4 \pm 6.4$ & $120.5 \pm 1.8 ; 88$ & - & & $\sim 120$ \\
\hline $\begin{array}{l}\text { тукурингрского комплек- } \\
\text { ca, обр. Б-14-1 }\end{array}$ & Плагиоклаз & $151.5 \pm 3.8$ & $121.1 \pm 3.4 ; 60$ & $156.8 \pm 2.0 ; 31$ & $156.8 \pm 4.0$ & $\sim 121$ \\
\hline Пегматит, обр. Б-3 & Полевой шпат & $153.2 \pm 3.4$ & $128.8 \pm 3.1 ; 29$ & $151.2 \pm 3.2 ; 37$ & $151.2 \pm 3.2$ & $\sim 129$ \\
\hline $\begin{array}{l}\text { Гранодиорит амуджи- } \\
\text { канского комплекса, } \\
\text { обр. Б-19 }\end{array}$ & Роговая обманка & $128.9 \pm 2.8$ & $131.7 \pm 2.4 ; 76$ & - & $131.7 \pm 2.4$ & - \\
\hline $\begin{array}{l}\text { Гранит амуджиканского } \\
\text { комплекса, обр. Б-16 }\end{array}$ & $\begin{array}{c}\text { " } \\
\text { Плагиоклаз }\end{array}$ & $\begin{array}{l}134.5 \pm 3.0 \\
128.5 \pm 3.6\end{array}$ & $\begin{array}{l}134.5 \pm 2.8 ; 96 \\
131.5 \pm 5.2 ; 57\end{array}$ & - & $134.5 \pm 2.8$ & - \\
\hline $\begin{array}{l}\text { Лейкогранит амуджи- } \\
\text { канского комплекса, } \\
\text { обр. Б-14-2 }\end{array}$ & Роговая обманка & $117.2 \pm 3.6$ & $119.3 \pm 3.4 ; 38$ & $131.6 \pm 4.2 ; 42$ & $131.6 \pm 4.2$ & $\sim 119$ \\
\hline Лампрофир, обр. Б-30 & Плагиоклаз & $124.2 \pm 3.4$ & $121.3 \pm 2.4 ; 40$ & $125.2 \pm 2.4 ; 38$ & $125.2 \pm 2.4$ & $\sim 121$ \\
\hline Лампрофир, обр. Б-18 & Роговая обманка & $132.0 \pm 3.8$ & $125.2 \pm 3.4 ; 78$ & - & $125.2 \pm 3.4$ & - \\
\hline
\end{tabular}

Примечание. Прочерк - возраст не рассчитывался. Номера образцов соответствуют номерам в тексте и на рисунках. Значение возраста термального события округлено до целых чисел.

надежное плато с соответствующим возрастом 119.6 2.2 млн лет (57\% выделенного ${ }^{39} \mathrm{Ar}$ ) (см. рис. 3 , табл. 1, 2), которое в пределах погрешности совпадает с упомянутой выше датировкой $121.3 \pm 3.0$ млн лет плагиоклаза из этого же образца.

На аргонограмме для роговой обманки-2, развитой по плоскости рассланцевания в том же обр. Б- 11 , достаточно четко выделяется плато с возрастом 110.8+4.2 млн лет (см. рис. 3) (71 \% выделенного ${ }^{39} \mathrm{Ar}$ ), рассматриваемым нами в качестве возраста новообразованного амфибола, фиксирующего заключительный этап преобразований исследуемого образца. Кроме того, обращает на себя внимание значимая (20\% выделенного аргона) еще одна низкотемпературная ступень с возрастом 93.1+7.0 млн лет (см. табл. 1, 2; рис. 3), которая связывается нами с более поздними наложенными процессами.

Близкие возрастные закономерности выявлены и при анализе биотита из гнейсовидных гранитов (обр. Б-2) тукурингрского комплекса, отобранных в непосредственной близости от месторождения (см. рис. 2). Аргонограмма для указанного минерала имеет отчетливую восходящую ступенчатую форму (см. рис. 3), что принято рассматривать как признак проявления нескольких этапов термальных процессов. Возраст наиболее раннего этапа, согласно расчетам по третьей-пятой ступеням (редуцированное плато), составляет 113.6 +4.0 млн лет (49 \% выделенного $\left.{ }^{39} \mathrm{Ar}\right)$, более позднего - по отчетливой низкотемпературной ступени - 90.0 3.2 млн лет (18 \% выделенного аргона) (см. табл. 1, 2; рис. 3). Датировка высокотемпературной ступени биотита Б-2 составила $153.1 \pm 1.9$ млн лет $\left(25 \%\right.$ выделенного $\left.{ }^{39} \mathrm{Ar}\right)$ (см. табл. 1, 2; рис. 3) и интерпретируется как нижний возрастной предел, который может быть близок к начальному ненарушенному возрасту.

Несколько разновозрастных событий выявлено и при анализе породообразующих минералов другого образца гранитов тукурингрского комплекса (обр. Б-14-1), отобранного из этого же массива. На гра- 

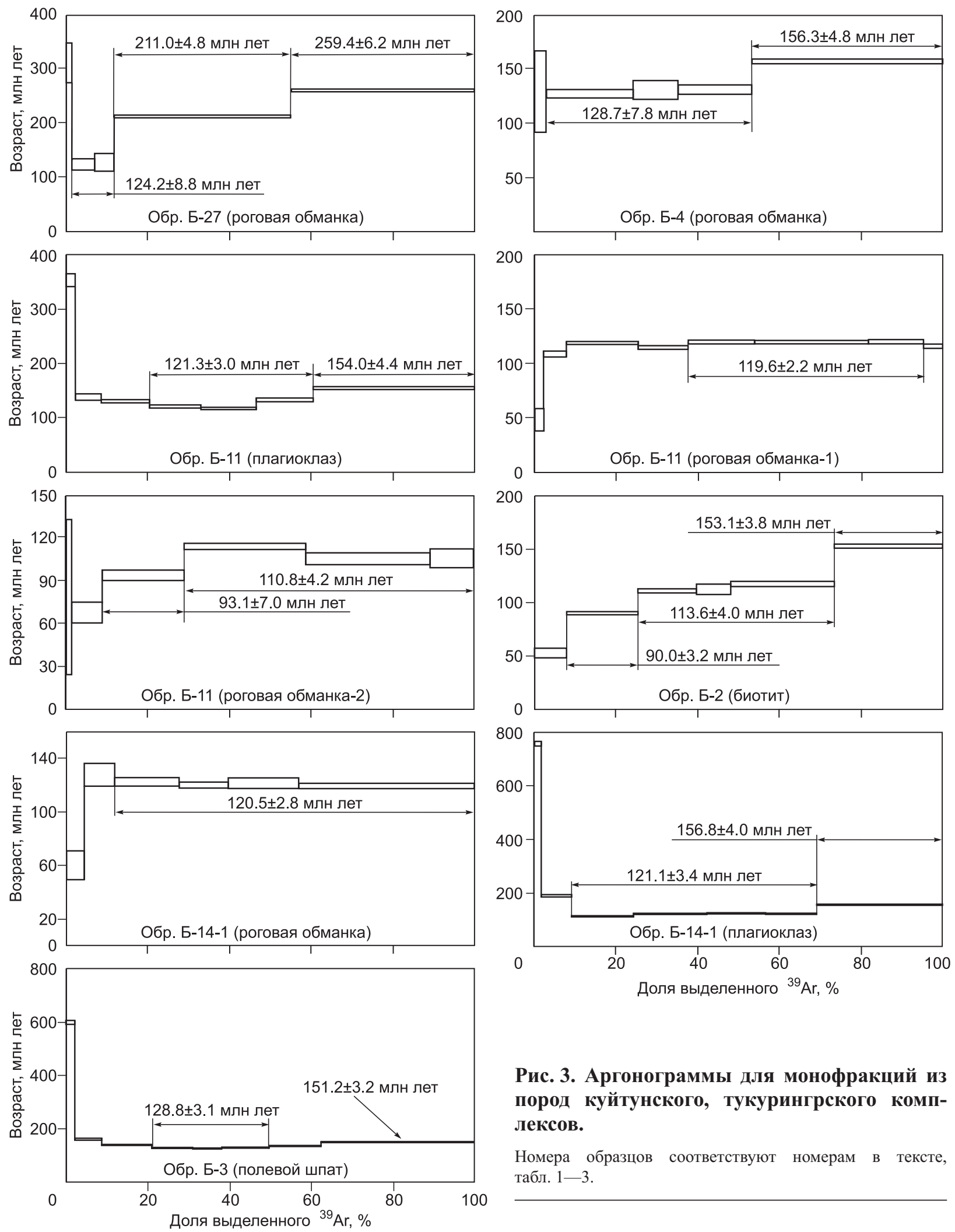

Рис. 3. Аргонограммы для монофракций из пород куйтунского, тукурингрского комплексов.

Номера образцов соответствуют номерам в тексте, табл. $1-3$.

фике ${ }^{40} \mathrm{Ar} /{ }^{39} \mathrm{Ar}$ возрастного спектра плагиоклаза (см. рис. 3) датировка высокотемпературной ступени составляет $156.8+4.0$ млн лет $\left(31 \%\right.$ выделенного $\left.{ }^{39} \mathrm{Ar}\right)$. По среднетемпературной части аргонового спектра, представленной последовательностью статистически не различимых (в пределах $\pm 2 \sigma$ ) четырех ступеней, нижняя оценка времени наложенного процесса составила 121.1 33.4 млн лет $(60 \%$ выделенного ${ }^{39} \mathrm{Ar}$ ) (см. табл. 1, 2). С этим значением в пределах погрешности совпадает возраст роговой обманки 
обр. Б-14-1, рассчитанный по четырем температурным ступеням, образующим плато, соответствующее возрасту $120.5 \pm 2.8$ млн лет ( $88 \%$ выделенного ${ }^{39} \mathrm{Ar}$ ) (см. табл. 1,2 ; рис. 3 ).

Широко распространены в пределах выходов гранитоидов тукурингрского комплекса жильные тела пегматитов, обычно рассматриваемые в качестве заключительной фазы данного комплекса. График ступенчатого нагрева полевого шпата из обр. Б-3 имеет сложную седлообразную форму (см. рис. 3 ; табл. 1,2$)$. При этом возраст конечной высокотемпературной ступени соответствует $151.2 \pm 3.2$ млн лет (37 \% выделенного $\left.{ }^{39} \mathrm{Ar}\right)$. Что касается среднетемпературной части, расчеты, проведенные по трем ступеням (редуцированное плато), показывают возраст $128.8 \pm 3.1$ млн лет (29 \% выделенного $\left.{ }^{39} \mathrm{Ar}\right)$, интерпретируемый как максимальный возрастной предел наложенного процесса.

Следующим по возрасту магматическим комплексом, проявленным в пределах месторождения, является амуджиканский. Породы этого комплекса формируют многочисленные разнообразные по формам и размерам массивы. В пределах рассматриваемого района они обрамляют месторождение Березитовое, локализованное в гранитоидах тукурингрского комплекса, в виде своеобразной подковы (см. рис. 1). Геохронологические исследования выполнены для минералов, выделенных из гранодиоритов, гранитов, а также даек лейкогранитов.

Графики ступенчатого отжига для роговой обманки из гранодиоритов (обр. Б-19), гранитов (обр. Б-16) во многом сходны между собой. На них отчетливо выделяется плато с возрастами $131.7 \pm 2.4$ млн лет $\left(76 \%\right.$ выделенного $\left.{ }^{39} \mathrm{Ar}\right)$ и $134.5 \pm 2.8$ млн лет $\left(96 \%\right.$ выделенного $\left.{ }^{39} \mathrm{Ar}\right)$ соответственно (см. рис. 4 ; табл. 1, 2). Аргонограмма плагиоклаза из гранита (обр. Б-16) имеет слабовыраженный ступенчатый характер с плато, соответствующим возрасту $131.5 \pm 5.2$ млн лет $\left(57 \%\right.$ выделенного $\left.{ }^{39} \mathrm{Ar}\right)$.

Несколько более сложный характер имеет график ступенчатого отжига для роговой обманки из дайки лейкогранита амуджиканского комплекса (обр. Б-14-2), прорывающей граниты тукурингрского комплекса (см. рис. 1,4$)$. Экспериментальные значения третьей-пятой ступеней (см. табл. 1,2$)$ образуют редуцированное плато с возрастом $119.3 \pm 3.4$ млн лет (38 \% выделенного $\left.{ }^{39} \mathrm{Ar}\right)$. Однако нельзя не отметить, что средневзвешенное значение для широких шестой и седьмой высокотемпературных ступеней (см. табл. 1) соответствует датировке $131.6 \pm 4.2$ млн лет ( $42 \%$ выделенного $\left.{ }^{39} \mathrm{Ar}\right)$, и именно она, по мнению авторов, в наибольшей степени приближена к возрасту кристаллизации расплава, а возраст $119.3+3.4$ млн лет фиксирует этап проявления наложенных процессов.

Таким образом, можно отметить, что возраст исследованных гранитоидов амуджиканского комплекса может быть определен в интервале 135-132 млн лет, при том, что для лейкогранита (обр. Б-14-2) отмечается этап наложенных процессов на рубеже 119 млн лет.

Наиболее молодыми магматическими образованиями в пределах рассматриваемого района являются дайки лампрофиров, которые, согласно легенде к новому поколению геологических карт [Козак, Вахтомин, 2000а,б], относятся к заключительной фазе амуджиканского комплекса. Нами были исследованы два образца таких даек (обр. Б-18, Б-30) непосредственно в пределах месторождения (см. рис. 2).

На аргонограмме для роговой обманки из обр. Б-18 отчетливо выделяется плато (см. рис. 4) с возрастом 125.2 \pm 3.4 млн лет $\left(78 \%\right.$ выделенного $\left.{ }^{39} \mathrm{Ar}\right)$, при этом возрастная оценка для второй и третьей ступеней также соответствует $125.1 \pm 2.4$ млн лет $\left(13 \%\right.$ выделенного $\left.{ }^{39} \mathrm{Ar}\right)$ (см. табл. 1, 2; рис. 4). Аргонограмма плагиоклаза из другого образца лампрофира (обр. Б-30) имеет форму «седла». При этом зна-

Таблица 3 . Интерпретация результатов ${ }^{40} \mathrm{Ar} /{ }^{39} \mathrm{Ar}$ геохронологических исследований для гидротермально-метасоматических рудных образований

\begin{tabular}{|c|c|c|c|c|c|}
\hline \multirow[b]{2}{*}{ Объект, номер образца } & \multicolumn{4}{|c|}{ Экспериментальные данные } & \multirow{2}{*}{$\begin{array}{c}\text { Интерпретация } \\
\text { Возраст гидротер- } \\
\text { мально-метасома- } \\
\text { тического процесса, } \\
\text { млн лет }\end{array}$} \\
\hline & Минерал & $\begin{array}{l}\text { Интеграль- } \\
\text { ный возраст, } \\
\text { млн лет }\end{array}$ & $\begin{array}{c}\text { Возраст по плато, } \\
\text { млн лет; количество } \\
\text { выделенного }{ }^{39} \mathrm{Ar}, \%\end{array}$ & $\begin{array}{l}\text { Возраст высокотем- } \\
\text { пературной ступени, } \\
\text { млн лет; количество } \\
\text { выделенного }{ }^{39} \mathrm{Ar}, \%\end{array}$ & \\
\hline $\begin{array}{l}\text { Гранат-кварц-мусковит-сери- } \\
\text { цит-калишпатовый метасома- } \\
\text { тит, обр. А-439 }\end{array}$ & Серицит & $140.3 \pm 2.6$ & $132.4 \pm 2.2 ; 84$ & - & $132.4 \pm 2.2$ \\
\hline $\begin{array}{l}\text { Мусковит-кварц-серицитовый } \\
\text { метасоматит, обр. А-440 }\end{array}$ & $\gg$ & $132.0 \pm 2.9$ & $131.3 \pm 2.3 ; 96$ & - & $131.3 \pm 2.3$ \\
\hline $\begin{array}{l}\text { Серицит-кварцевый метасома- } \\
\text { тит, обр. ПВ-18 }\end{array}$ & $»$ & $125.4 \pm 3.2$ & $125.3 \pm 2.4 ; 94$ & - & $125.3 \pm 2.4$ \\
\hline
\end{tabular}

Примечание. Прочерк - возраст не рассчитывался. Аналитические данные для обр. А-439 и А-440 заимствованы из публикаций [Сорокин и др., 2008; Мельников и др., 2009]. Номера образцов соответствуют номерам в тексте и на рисунках. 

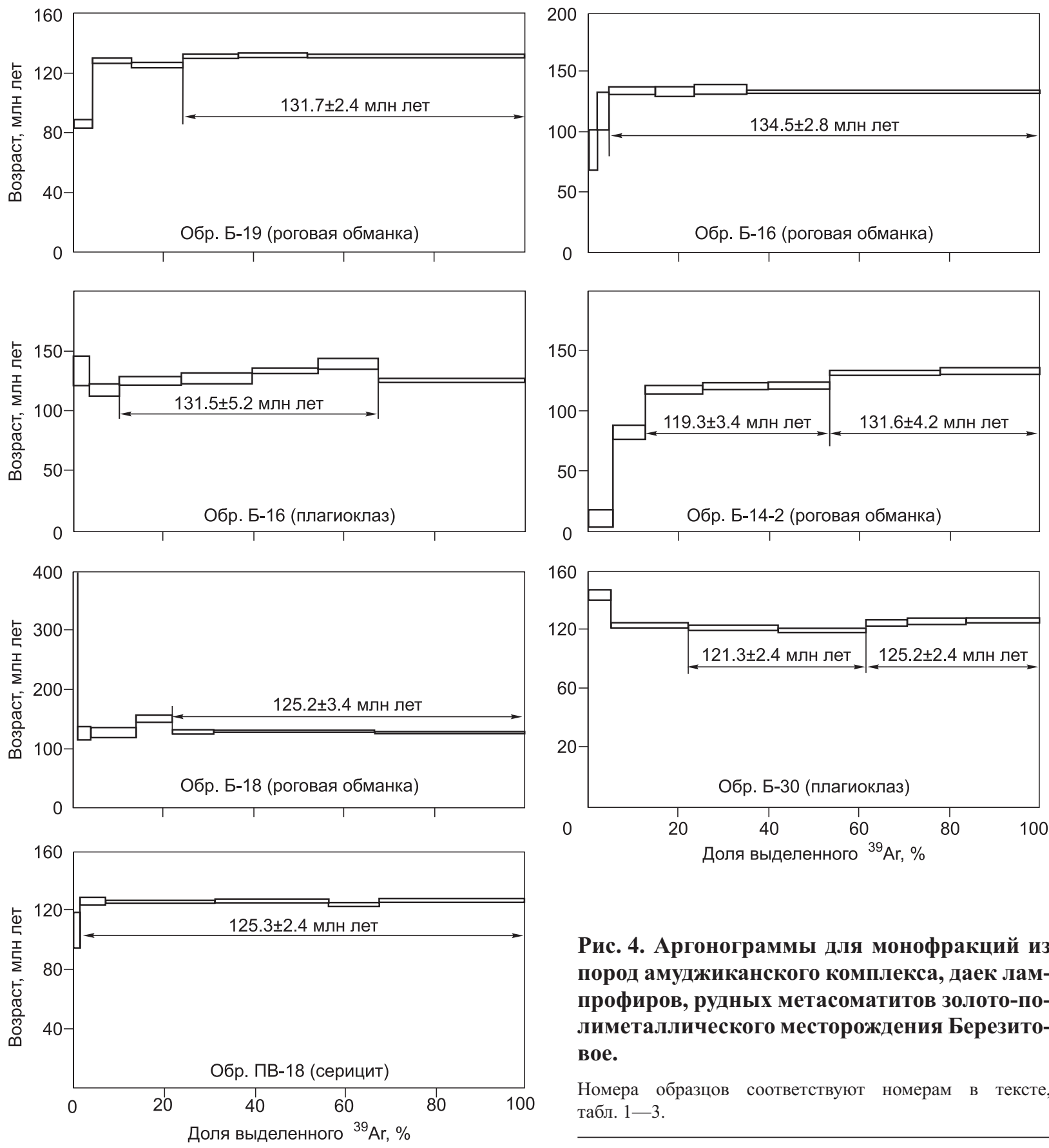

Рис. 4. Аргонограммы для монофракций из пород амуджиканского комплекса, даек лампрофиров, рудных метасоматитов золото-полиметаллического месторождения Березитовое.

Номера образцов соответствуют номерам в тексте, табл. $1-3$.

чение возраста для трех высокотемпературных ступеней - 125.2 2.4 млн лет (38 \% выделенного $\left.{ }^{39} \mathrm{Ar}\right)$, а двух среднетемпературных ступеней $121.3 \pm 2.4$ млн лет $\left(40 \%\right.$ выделенного $\left.{ }^{39} \mathrm{Ar}\right)$ (см. табл. 1, 2).

Особую группу данных формируют результаты геохронологических исследований собственно рудных образований. Ранее [Сорокин и др., 2008; Мельников и др., 2009] были получены оценки возраста рудных метасоматитов, отобранных из основного рудного тела в центральной части месторождения. Учитывая, что эти данные будут использованы нами в дальнейшем, мы сочли необходимым привести их ниже, не сопровождая графическим материалом, опубликованным в указанных источниках. Характер графика ступенчатого отжига серицита из мусковит-кварц-серицитового метасоматита (обр. А-440) позволяет выделить плато с возрастом $131.3 \pm 2.3$ млн лет (92\% выделенного ${ }^{39} \mathrm{Ar}$ ) (см. табл. 3). Возраст плато серицита из гранат-кварц-мусковит-серицит-калишпатового метасоматита (обр. А-439) соответствует возрасту 132.4 22.2 млн лет (см. табл. 3) (84 \% выделенного $\left.{ }^{39} \mathrm{Ar}\right)$.

Помимо этого, нами были исследованы серицит-кварцевые метасоматиты (обр. ПВ-18), наложенные на гранат-кварц-мусковит-серицит-калишпатовые разности. На аргонограмме серицита (см. рис. 4), 
выделенного из этой породы, отчетливо выделяется плато с возрастом $125.3 \pm 2.4$ млн лет (94 \% выделенного ${ }^{39} \mathrm{Ar}$ ) (см. табл. 1,3$)$, что надежно фиксирует возраст проявления гидротермального процесса.

\section{ОБСУЖДЕНИЕ РЕЗУЛЬТАТОВ}

В результате проведенных исследований получен значительный объем изотопных данных, позволяющих проследить как общую хронологию формирования магматизма, так и наложенных процессов, в том числе гидротермальных.

Как было показано выше, для трахиандезибазальтов (обр. Б-27), относимых к чичаткинскому [Козак, Вахтомин, 2000а,б] или куйтунскому [Вольский, 1979] комплексу, нами получена нижняя оценка возраста 259.4⒍2 млн лет. Она согласуется с ранее установленным возрастом (но с большой погрешностью) для этих же вулканитов 265+15 млн лет (Rb-Sr метод) [Козак, Вахтомин, 2000a,б], но несколько древнее значения, приводимого для риолитов этого комплекса $-246 \pm 2$ млн лет (U-Pb метод) [Ларин и др., 2011].

Следующая группа возрастов установлена для интрузивных пород тукурингрского комплекса. Эти породы претерпели несколько этапов тектонических дислокаций термальных воздействий, что выразилось в сложной форме графиков ступенчатого нагрева. Однако обращает на себя внимание присутствие в спектрах плагиоклазов (обр. Б-4, Б-11, Б-14-1), полевого шпата (обр. Б-3) и биотита (обр. Б-2) высокотемпературных ступеней с возрастами более 150 млн лет, что вряд ли является случайным. Принимая во внимание значения, рассчитанные по редуцированным плато или высокотемпературным ступеням, можно с достаточной степенью уверенности предполагать, что возраст формирования исследованных пород (габбро, граниты, пегматиты) может быть определен интервалом 157-151 млн лет. Близкий интервал формирования комплекса 150-145 млн лет приводится и на основании результатов датирования пород тукурингрского комплекса U-Pb методом по цирконам [Ларин и др., 2010].

Для гранодиоритов, гранитов, лейкогранитов амуджиканского комплекса нами получены надежные значения возрастов в интервале 134-132 млн лет. Ранее на основании $\mathrm{K}-\mathrm{Ar}, \mathrm{Rb}-\mathrm{Sr}$ датировок этот комплекс считался юрским [Козак, Вахтомин, 2000a,б]. В то же время в последние годы для этих пород получена серия датировок U-Pb методом в интервале 132-128 млн лет [Ларин и др., 2005], что хорошо согласуется с нашими данными.

Существенно более молодые возрасты установлены нами для лампрофиров, которые в рамках существующей легенды отнесены [Козак, Вахтомин, 2000а,б] к амуджиканскому комплексу. На основании проведенных исследований их возраст оценивается нами $\sim 125$ млн лет, что может свидетельствовать о том, что эти породы представляют самостоятельный комплекс.

Переходя к возрасту оруденения, следует акцентировать внимание на то, что для двух типов метасоматитов получены два значения возрастов. Мусковит-кварц-серицитовые и гранат-кварц-мусковитсерицит-калишпатовые рудные метасоматиты имеют возраст в интервале 132-131 млн лет [Сорокин и др., 2008; Мельников и др., 2009], что позволяет связать их формирование с амуджиканским комплексом. В то же время возраст наложенных на них серицит-кварцевых метасоматитов составляет 125 млн лет, и он близок возрасту становления даек лампрофиров. Таким образом, на основании геохронологических данных на Березитовом месторождении устанавливается, как минимум, два этапа рудообразования, что подтверждается структурными и минералогическими исследованиями [Вах и др., 2009].

Итак, в результате проведенных исследований получены надежные датировки для широкого спектра разновозрастных магматических пород, представленных в пределах рудного поля и вблизи месторождения Березитовое, а также гидротермальных рудных образований. В то же время применение ${ }^{39} \mathrm{Ar} /$ ${ }^{40} \mathrm{Ar}$ метода позволяет также оценить возраст наложенных термальных процессов, связанных не только с гидротермальной деятельностью, но и с тектоническими дислокациями.

Анализ возрастов, которые отражают наложенные процессы, указывает на то, что последние в большинстве случаев отвечают интервалу 121-119 млн лет, при подчиненном количестве значений $\sim 211, \sim 129,125-124,114-90$ млн лет (см. табл. 1, 2). Наиболее древнее значение $\sim 211$ млн лет выявлено в аргонограмме амфибола из трахибазальта куйтунского комплекса (см. рис. 3; табл. 1, 2), и оно хорошо коррелирует с одним из этапов проявления раннемезозойского магматизма в пределах рассматриваемого региона [Ларин и др., 2011].

Следующий (в хронологическом порядке) термальный эпизод имеет возраст 129 млн лет и проявлен в габброидах (обр. Б-4) и пегматитах (обр. Б-3) тукурингрского комплекса (см. рис. 3; табл. 1, 2). Кроме того, близкий возраст имеют и гранат-кварц-мусковит-серицит-калишпатовые рудные метасоматиты (132-131 млн лет), представляющие первый ранний этап рудообразования. В связи с тем, что этот возрастной рубеж близок возрасту остывания гранитоидов амуджиканского комплекса (134-132 млн лет), представляется вполне логичным связывать его с воздействием указанных гранитоидов.

Несколько более молодой возраст наложенных процессов 125-124 млн лет фиксируется в аргонограмме роговой обманки из трахибазальта куйтунского комплекса (обр. Б-27). Этому же возрасту со- 
ответствуют небольшие ступени (до $14 \%$ выделенного ${ }^{39} \mathrm{Ar}$ ) в низкотемпературной части спектров роговой обманки из гранодиорита (обр. Б-19) и плагиоклаза из гранита (обр. Б-16) амуджиканского комплекса (см. табл. 1). Важно отметить, что на этот же возрастной рубеж приходится становление даек лампрофиров (обр. Б-18, Б-30) (см. табл. 1, 2; рис. 4) и связываемого с ними второго этапа рудообразования, а именно формирование серицит-кварцевых метасоматитов (обр. ПВ-18) (см. табл. 1, 3; рис. 4).

Наконец, два наиболее поздних и четко представленных термальных события - 121-119 и 114 90 млн лет. Первый из них реконструируется по аргонограммам плагиоклаза и роговой обманки из гнейсовидных гранитов тукурингрского комплекса (обр. Б-11, Б-14-1) (см. табл. 1, 2; рис. 3). Важно отметить, что в этих гранитоидах возраст роговой обманки существенно моложе возраста высокотемпературных ступеней плагиоклаза, что может свидетельствовать о влиянии не только (или не столько!) термального, но и деформационного процесса, когда проявляется большая устойчивость плагиоклаза по отношению к амфиболу [Shea, Kronenberg, 1992]. Таким образом, учитывая характер экспериментальных, а также отсутствие геохронологических данных, свидетельствующих о проявлении магматизма в пределах рассматриваемой структуры на рубеже 121-119 млн лет, мы склонны объяснять это термальное событие дислокационными процессами. В подтверждение сказанного можно указать на то, что этот возрастной рубеж в пределах рассматриваемого региона приходится на формирование комплексов метаморфических ядер [Котов и др., 2009; Сальникова и др., 2012].

Термальное событие 114-90 млн лет фиксируется возрастом роговой обманки-2 (обр. Б-11), развитой по плоскости сланцеватости - 110.8+4.2 млн лет, а также возрастом низкотемпературной ступени в этом же образце - 93.1+7.0 млн лет. Кроме того, в указанном интервале находятся возрастные оценки плато (113.6+4.0 млн лет) и низкотемпературной ступени для биотита из гнейсовидных гранитов (обр. Б-2) тукурингрского комплекса (см. табл. 1, 2; рис. 3). При отсутствии геохронологических свидетельств проявления магматической активности в этот период, а также при том, что он фиксируется в том числе и возрастом роговой обманки, развитой по системе сланцеватости, мы считаем возможным связать это термальное событие, как и предыдущее (121-119 млн лет), дислокационными процессами.

В заключение обратимся к тектонической интерпретации полученных данных. Нахождение Березитового месторождения в пределах южной окраины Селенгино-Станового супертеррейна в непосредственной близости от структур Монголо-Охотского пояса (см. рис. 1) наводит на мысль о том, что это месторождение может быть связано с заключительными этапами образования пояса. В то же время коллизионные процессы завершились до формирования месторождения. При этом одни исследователи предполагают раннемеловой ( 140 млн лет) возраст коллизии [Ларин и др., 2006], другие [Парфенов и др., 1999; He et al., 2005; Сорокин и др., 2010б] допускают, что начало орогенических событий могло произойти и в ранней юре. Таким образом, по отношению к Монголо-Охотскому складчатому поясу месторождение является постколлизионным.

С другой стороны, месторождение Березитовое находится в области проявления позднемезозойского магматизма, обусловленного взаимодействием восточной окраины Азии и тихоокеанских океанических плит. И здесь нельзя не отметить, что возраст гранитоидов амуджиканского комплекса (134132 млн лет), проявленного в пределах Селенгино-Станового супертеррейна, соответствует возрасту гранитоидов верхнеамурского и буриндинского комплексов (140-127 млн лет), широко распространенных в структуре Аргунского террейна [Сорокин и др., 2004, 2009, 2010а].

Широкое распространение позднемезозойского магматизма вдоль тихоокеанской окраины Азии указывает на связь его формирования с взаимодействием плит на границе океан-континент, однако характер этого взаимодействия был и остается предметом острых дискуссий. Среди возможных вариантов предполагается обстановка активной континентальной окраины [Натальин, 1991; Натальин, Борукаев, 1991; Гордиенко и др., 2000] или чередование обстановок активной и трансформной континентальных окраин [Ханчук, Иванов, 1999; Ханчук, 2000; Сахно, 2001; Геодинамика..., 2006].

Результаты исследований мезозойского магматизма восточной части Азии свидетельствует о том, что он характеризуется особенностями, не свойственными обстановке активной континентальной окраины [Сахно, 2001; Wang et al., 2006; Сорокин и др., 2009; Zang et al., 2010]. В этой связи его образование, по крайней мере, в раннемеловое время следует связывать с несубдукционным этапом формирования восточной окраины Азии [Ханчук, 2000; Геодинамика..., 2006].

Помимо общей конформности поясов распространения позднемезозойского магматизма и тихоокеанской окраины Азии следует отметить как дискретность его проявления, так и омоложение в восточном направлении. Такая тенденция была выявлена достаточно давно, но в последние годы на основе современных аналитических методик была показана четкая зональность в расположении разновозрастных поясов вдоль тихоокеанской окраины от Большехинганского пояса ( 160-140 млн лет) в глубине континента до Кореи и Японии ( 80 млн лет) [Wang et al., 2006; Zhang et al., 2010]. Однако при отчетливо выраженной зональности возрастных характеристик магматизма возраст оруденения в разных геологических структурах остается весьма близким: золото-полиметаллическое месторождение Березито- 
вое - 132-131 и 125 млн лет (данное исследование), золоторудное месторождение Токур — 122 млн лет [Сорокин и др., 2011], золоторудное месторождение Кировское - 128 млн лет [Моисеенко и др., 1999], Cu-Мо-порфировое (с золотом) месторождение Боргуликан - 123-122 млн лет [Сотников и др., 2007б], Мо-порфировое (с золотом) рудопроявление Выходное - 125-122 млн лет [Сотников и др., 2007a], золото-серебряное рудопроявление Десс - 130-122 млн лет [Бучко и др., 2010, 2012а], что пока не находит объяснения.

Авторы выражают искреннюю признательность С.Д. Соколову за критический анализ рукописи, дискуссию, а также конструктивные замечания и рекомендации.

Исследования выполнены при поддержке Президиума ДВО РАН (проекты 12-II-CO-08-030), РФФИ (проекты 11-05-00758, 09-05-00728-а).

\section{ЛИТЕРАТУРА}

Берзина А.П., Сотников В.И. Магматические центры с Сu-Мо-порфировым оруденением Центрально-Азиатского подвижного пояса (на примере Сибири и Монголии) // Геология и геофизика, 1999, т. 40 (11), с. $1605-1618$.

Берзина А.П., Берзина А.Н., Гимон В.О. Сорское Сu-Мо-порфировое месторождение (Кузнецкий Алатау): магматизм, влияние мантийного плюма на развитие рудно-магматической системы // Геология и геофизика, 2011, т. 52 (12), с. 1974-1986.

Бучко И.В., Сальникова Е.Б., Котов А.Б., Ларин А.М., Великославинский С.Д., Сорокин А.А, Сорокин А.П., Яковлева С.З. Палеопротерозойские габбро-анортозиты Селенгино-Станового супертеррейна южного обрамления Сибирского кратона // ДАН, 2006, т. 407, № 4, с. 502 — 505.

Бучко И.В., Сорокин А.А., Сальникова Е.Б., Котов А.Б., Ларин А.М., Сорокин А.П., Великославинский С.Д., Яковлева С.3. Возраст и тектоническая позиция Кенгурак-Сергачинского габброанортозитового массива (Селенгино-Становой супертеррейн южного обрамления Сибирского кратона) // Стратиграфия. Геологическая корреляция, 2008, т. 16, № 4, с. 3-13.

Бучко И.В., Сорокин А.А., Пономарчук В.А., Травин А.В., Сорокин А.П., Бучко Ир.В. Возраст и геодинамическая обстановка формирования золото-серебряного оруденения рудопроявления Десс Северо-Становой металлогенической зоны (юго-восточное обрамление Северо-Азиатского кратона) // ДАН, 2010, т. 435, № 4, с. 506-509.

Бучко И.В., Сорокин А.А., Пономарчук В.А., Травин А.В., Бучко Ир.В. Возраст и связь с магматизмом золото-серебряного оруденения рудопроявления Десс Северо-Становой металлогенической зоны (юго-восточное обрамление Северо-Азиатского кратона) // Тихоокеанская геология, 2012а, т. 31, № 2 , с. $69-74$.

Бучко И.В., Сорокин А.А., Пономарчук В.А., Изох А.Э. Геохимические особенности и геодинамическая обстановка формирования Лукиндинского дунит-троктолит-габбрового массива (юго-восточное обрамление Сибирской платформы) // Геология и геофизика, 2012б, т. 53 (7), с. 834-850.

Вах А.С. Золотая минерализация и особенности генезиса Березитового полиметаллического месторождения (Верхнее Приамурье). Владивосток, ДВГИ ДВО АН СССР, 1989, 23 с.

Вах А.С., Моисеенко В.Г., Степанов В.А., Авченко О.В. Березитовое золото-полиметаллическое месторождение // ДАН, 2009, т. 425, № 2, с. 204-207.

Вольский А.С., Озерский А.С., Семенов В.С. Геологическая карта региона БАМ. М-б 1:500 000. N-51-А. Л., ВСЕГЕИ, 1979.

Гаврикова С.Н., Николаева Л.Л., Галанин А.В., Соколов С.Ю. Ранний докембрий южной части Становой складчатой области. М., Недра, 1991, 171 с.

Геодинамика, магматизм и металлогения востока России / Ред. А.И. Ханчук. Кн. 1. Владивосток, Дальнаука, 2006, 572 с.

Гордиенко И.В., Климук В.С., Цюань Хень. Верхнеамурский вулканоплутонический пояс Восточной Азии (строение, состав, геодинамические условия формирования) // Геология и геофизика, 2000, т. 41 (12), с. $1655-1669$.

Добрецов Н.Л., Буслов М.М. О проблемах геодинамики, тектоники и металлогении складчатых поясов // Геология и геофизика, 2011, т. 52 (12), с. 1911-1926.

Донская Т.В., Гладкочуб Д.П., Мазукабзов А.М., де Ваэле В., Пресняков С.Л. Позднетриасовая Катаевская вулканоплутоническая ассоциация Западного Забайкалья - фрагмент активной континентальной окраины Монголо-Охотского океана // Геология и геофизика, 2012, т. 53 (1), с. 30 - 49.

Козак 3.П., Вахтомин К.Д. Государственная геологическая карта Российской Федерации. М-б 1:200 000. Издание второе. Становая серия. N-51-XV (Уруша). СПб., ВСЕГЕИ, 2000а. 
Козак 3.П., Вахтомин К.Д. Государственная геологическая карта Российской Федерации. М-б 1:200 000. Издание второе. Становая серия. N-51-XVI (Тахтамыгда). СПб., ВСЕГЕИ, 2000б.

Котов А.Б., Сорокин А.А., Сальникова Е.Б., Сорокин А.П., Ларин А.М., Великославинский С.Д., Беляков Т.В., Анисимова И.В., Яковлева С.З. Мезозойский возраст гранитоидов Бекетского комплекса (Гонжинский блок Аргунского террейна Центрально-Азиатского складчатого пояса) // ДАН, 2009, т. 429, № 6, с. 779-783.

Куликова 3.И., Спиридонов А.М., Зорина Л.Д. Метасоматиты Карийского золоторудного месторождения (Восточное Забайкалье) // Геология и геофизика, 2007, т. 48 (11), с. 1161-1175.

Ларин А.М., Сорокин А.А., Котов А.Б., Сальникова Е.Б., Великославинский С.Д., Бучко И.В. Корреляция возрастных рубежей мезозойского магматизма северного и южного обрамлений восточного фланга Монголо-Охотского складчатого пояса // Материалы научного совещания «Геодинамическая эволюция литосферы Центрально-Азиатского подвижного пояса (от океана к континенту)». Т. 2. Иркутск, ИЗК СО РАН, 2005, с. 19-22.

Ларин А.М., Сальникова Е.Б., Котов А.Б., Глебовицкий В.А., Великославинский С.Д., Сорокин А.А., Яковлева С.З., Федосеенко А.М., Анисимова И.В. Раннемеловой возраст регионального метаморфизма становой серии Джугджуро-Становой складчатой области: геодинамические следствия // ДАН, 2006, т. 409, № 2, с. 222-226.

Ларин А.М., Великославинский С.Д., Котов А.Б., Сальникова Е.Б., Глебовицкий В.А., Ковач В.П. Тектономагматическая эволюция Джугджуро-Станового и Селенгино-Станового супертеррейнов Центрально-Азиатского складчатого пояса // Материалы конференции «Вопросы геологии и комплексного освоения природных ресурсов восточной Азии». Благовещенск, ИГиП ДВО РАН, 2010, с. 25-26.

Ларин А.М., Котов А.Б., Сальникова Е.Б., Сорокин А.А., Сорокин А.П., Коршунов А.М., Великославинский С.Д., Яковлева С.З., Плоткина Ю.В. Возраст и тектоническое положение гранитов и вулканитов восточного окончания Селенгино-Витимского вулканоплутонического пояса // ДАН, 2011, т. 441, № 3, с. 363 - 368 .

Мартынюк М.В., Рямов С.А., Кондратьева В.А. Объяснительная записка к схеме корреляции магматических комплексов Хабаровского края и Амурской области. Хабаровск, Дальгеология, 1990, $215 \mathrm{c}$.

Мельников А.В., Сорокин А.А., Пономарчук В.А., Травин А.В., Сорокин А.П. Золото-полиметаллическое месторождение Березитовое (Восточная Сибирь): основные минералогические особенности, возраст и связь с магматизмом // Геология и геофизика, 2009, т. 50 (3), с. 258-265.

Моисеенко В.Г., Эйриш Л.В. Золоторудные месторождения востока России. Владивосток, Дальнаука, 1996, 352 с.

Моисеенко В.Г., Степанов В.А., Шергина Ю.П. Возраст золотого оруденения Бамского рудного узла // ДАН, 1997, т. 355, № 3, с. 369-371.

Моисеенко В.Г., Степанов В.А., Шергина Ю.П. Возраст формирования Кировского золоторудного месторождения Приамурья // ДАН, 1999, т. 369, № 3, с. 354-356.

Натальин Б.А. Мезозойская аккреционная и коллизионная тектоника юга Дальнего Востока СССР // Тихоокеанская геология, 1991, № 5, с. 3-23.

Натальин Б.А., Борукаев Ч.Б. Мезозойские сутуры на юге Дальнего Востока СССР // Геотектоника, 1991, № 1, с. 84-97.

Парфенов Л.М., Попеко Л.И., Томуртогоо О. Проблемы тектоники Монголо-Охотского орогенного пояса // Тихоокеанская геология, 1999, т. 18, № 5, с. $24-43$.

Парфенов Л.М., Берзин Н.А., Ханчук А.И., Бадарч Г., Беличенко В.Г., Булгатов А.Н., Дриль С.И., Кириллова Г.Л., Кузьмин М.И., Нокленберг У., Прокопьев А.В., Тимофеев В.Ф., Томуртогоо О., Янь Х. Модель формирования орогенных поясов Центральной и Северо-Восточной Азии // Тихоокеанская геология, 2003, т. 22, № 6, с. 7-41.

Поляков Г.В., Изох А.Э., Кривенко А.П. Платиноносные ультрамафит-мафитовые формации подвижных поясов Центральной и Юго-Восточной Азии // Геология и геофизика, 2006, т. 47 (12), с. $1227-$ 1241.

Пономарчук В.А., Лебедев Ю.Н., Травин А.В., Морозова И.П., Киселева В.Ю., Титов А.Т. Применение тонкой магнитно-сепарационной технологии в $\mathrm{K}-\mathrm{Ar},{ }^{40} \mathrm{Ar}-{ }^{39} \mathrm{Ar}, \mathrm{Rb}-\mathrm{Sr}$ методах датирования пород и минералов // Геология и геофизика, 1998, т. 39 (1), с. 55-64.

Попов Н.В., Котов А.Б., Постников А.А., Сальникова Е.Б., Шапорина М.Н., Ларин А.М., Яковлева С.З., Плоткина Ю.В., Федосеенко А.М. Возраст и тектоническое положение Чинейского расслоенного массива (Алданский щит) // ДАН, 2009, т. 424, № 4, с. 517—521. 
Прокофьев В.Ю., Бакшеев И.А., Зорина Л.Д., Беляцкий Б.В., Бортников Н.С. Первая оценка возраста золотых руд месторождения Дарасун (Восточное Забайкалье) Sm-Nd методом // ДАН, 2006, т. 409, № 5, с. 673 - 676 .

Сальникова Е.Б., Котов А.Б., Ковач В.П., Великославинский С.Д., Джан Б.-М., Сорокин А.А., Сорокин А.П., Ван К.-Л., Чан С.-Л., Толмачева Е.В. О возрасте гонжинской серии (Аргунский террейн Центрально-Азиатского складчатого пояса): результаты U-Pb и Lu-Hf изотопных исследований детритовых цирконов // ДАН, 2012, т. 444, № 5, с. 519-522.

Сахно В.Г. Позднемезозойско-кайнозойский континентальный вулканизм востока Азии. Владивосток, Дальнаука, 2001, 335 с.

Сорокин А.А., Пономарчук В.А., Сорокин А.П., Козырев С.К. Геохронология и корреляция мезозойских магматических образований северной окраины Амурского супертеррейна // Стратиграфия. Геологическая корреляция, 2004, т. 12, № 6, с. 38-54.

Сорокин А.А., Мельников А.В., Пономарчук В.А., Травин А.В., Сорокин А.П. Возраст и связь с магматизмом золото-полиметаллического месторождения Березитовое западной части Селенгино-Станового супертеррейна // ДАН, 2008, т. 421, № 1, с. 86-89.

Сорокин А.А., Сорокин А.П., Пономарчук В.А., Травин А.В., Мельникова О.В. Позднемезозойский вулканизм восточной части Аргунского супертеррейна (Дальний Восток): ${ }^{40} \mathrm{Ar} /{ }^{39} \mathrm{Ar}$ геохронологические и геохимические данные // Стратиграфия. Геологическая корреляция, 2009, т. 17, № 6, с. 90104.

Сорокин А.А., Ковач В.П., Котов А.Б., Сорокин А.П., Пономарчук В.А. Изотопно-геохимические $(\mathrm{Sr}, \mathrm{Nd})$ особенности и источники мезозойских магматических ассоциаций Умлекано-Огоджинского пояса (Приамурье) // ДАН, 2010а, т. 435, № 5, с. 677-682.

Сорокин А.А., Смирнова Ю.Н., Попеко Л.И., Сорокин А.П., Смирнов Ю.В. Особенности химического состава и тектонические условия накопления палеозойских терригенных отложений Ольдойского террейна (восточная часть Центрально-Азиатского складчатого пояса) // ДАН, 2010б, т. 435, № 3, c. $361-364$.

Сорокин А.А., Остапенко Н.С., Пономарчук В.А., Травин А.В. Возраст адуляра из жил золоторудного месторождения Токур (Монголо-Охотский орогенный пояс, Россия): результаты датирования ${ }^{40} \mathrm{Ar} /{ }^{39} \mathrm{Ar}$ методом // Геология рудных месторождений, 2011, т. 53, № 3, с. 297-304.

Сотников В.И., Пономарчук В.А., Сорокин А.А., Сорокин А.П., Гимон В.О. Возрастные рубежи формирования $\mathrm{Cu}-\mathrm{Mo-порфировых} \mathrm{месторождений} \mathrm{в} \mathrm{структурах} \mathrm{обрамления} \mathrm{Монголо-Охотского}$ орогенного пояса // ДАН, 2005, т. 403, № 4, с. 522-525.

Сотников В.И., Сорокин А.А., Пономарчук В.А., Травин А.В., Сорокин А.П., Гимон В.О. Геохронология мезозойских гранитоидов и связанного с ними молибденового оруденения западной части Джугджуро-Станового супертеррейна // ДАН, 2007а, т. 416, № 6, с. 794-798.

Сотников В.И., Сорокин А.А., Пономарчук В.А., Гимон В.О., Сорокин А.П. Возраст Мо-Сu$(\mathrm{Au})$-порфирового оруденения и магматических комплексов Боргуликанского рудного поля (Верхнее Приамурье) // Геология и геофизика, 2007б, т. 48 (2), с. $229-237$.

Травин А.В., Юдин Д.С., Владимиров А.Г., Хромых С.В., Волкова Н.И., Мехоношин А.С., Колотилина Т.Б. Термохронология Чернорудской гранулитовой зоны (Ольхонский регион, Западное Прибайкалье) // Геохимия, 2009, № 11, с. 1181-1199.

Ханчук А.И. Палеогеодинамический анализ формирования рудных месторождений Дальнего Востока России // Рудные месторождения континентальных окраин. Владивосток, Дальнаука, 2000, с. 534.

Ханчук А.И., Иванов В.В. Мезокайнозойские геодинамические обстановки и золотое оруденение Дальнего Востока России // Геология и геофизика, 1999, т. 40 (11), с. 1635-1645.

Цыганков А.А., Литвиновский Б.А., Джань Б.М., Рейков М., Лю Д.И., Ларионов А.Н., Пресняков С.Л., Лепехина Е.Н., Сергеев С.А. Последовательность магматических событий на позднепалеозойском этапе магматизма Забайкалья (результаты U-Pb изотопного датирования) // Геология и геофизика, 2010, т. 51 (9), с. 1249-1276.

Эйриш Л.В. Металлогения золота Приамурья (Амурская область, Россия). Владивосток, Дальнаука, 2002, 194 с.

Alexandrov P., Ruffet G., Cheillet A. Muscovite recrystallization and saddle-shaped ${ }^{40} \mathrm{Ar} /{ }^{39} \mathrm{Ar}$ age spectra: example from the Blond granite (Massif Central, France) // Geochim. Cosmochim. Acta, 2002, v. 66, № 10, p. $1793-1807$.

Baksi A.K. Reevaluation of plate motion models based on hotspot tracks in the Atlantic and Indian oceans // J. Geol., 1999, v. 107, № 1, p. 13-26. 
Berger B.W., York D. Geothermometry from ${ }^{40} \mathrm{Ar} /{ }^{39} \mathrm{Ar}$ dating experiments // Geochim. Cosmochim. Acta, 1981, v. 45, № 6, p. 795-811.

Cheilletz A., Ruffet G., Marignac C., Kolli O., Gasquet D., Feraud G., Bouillin J.P. ${ }^{40} \mathrm{Ar} /{ }^{39} \mathrm{Ar}$ dating of shear zones in the Variscan basement of Greater Kabylia (Algeria). Evidence of an Eo-Alpine event at $128 \mathrm{Ma}$ (Hauterivian-Barremian boundary): geodynamic consequences // Tectonophysics, 1999, v. 306, № 1, p. $97-116$.

Chikov B.M., Ponomarchuk V.A., Zinoviev S.V., Palessky S.V. Stress-Metamorphism and isotopic age of shear zone granitoid tectonites of Irtysh shear zone (Altai region) // Geotecton. Metallogen., 2002, v. 26, № $1-2$, p. $36-51$.

Fleck R.J., Sutter J.F., Elliot D.H. Interpretation of discordant ${ }^{40} \mathrm{Ar} /{ }^{39} \mathrm{Ar}$ age spectra of Mesozoic tholeiites from Antarctica // Geochim. Cosmochim. Acta, 1977, v. 41, № 1, p. 15-32.

Forster M.A., Lister G.M. The interpretation of ${ }^{40} \mathrm{Ar} /{ }^{39} \mathrm{Ar}$ apparent age spectra produced by mixing: application of the method of asymptotes and limits // J. Struct. Geol., 2004, v. 26, № 2, p. 287-305.

Gustafson L.B., Orquera W., McWilliams M., Castro M., Olivares O., Rojas G., Maluenda J., Mendez M. Multiple centers of mineralization in the Indio Muerto District, El Salvador, Chile // Econ. Geol., 2001, v. 96, № 2, p. 325-350.

He Z.J., Li J.Y., Mo S.G., Sorokin A.A. Geochemical discriminations of sandstones from the Mohe Foreland basin, northeastern China: tectonic setting and provenance // Sci. China. Series D. Earth Sci., 2005, v. 48, № 5, p. 613-621.

Rolland Y., Cox S.F., Corsini M. Constraining deformation stages in brittle-ductile shear zones from combined field mapping and ${ }^{40} \mathrm{Ar} /{ }^{39} \mathrm{Ar}$ dating: The structural evolution of the Grimsel Pass area (Aar Massif, Swiss Alps) // J. Struct. Geol., 2009, v. 31, № 11, p. 1377-1394.

Segev A. Synchronous magmatic cycles during the fragmentation of Gondwana: radiometric ages from the Levant and other provinces // Tectonophysics, 2000, v. 325, № 3-4, p. 257-277.

Shea W.T., Kronenberg A.K. Rheology and deformation mechanisms of an isotropic mica schist // J. Geophys. Res., 1992, v. 97, № B11, p. 15201-15237.

Wang F., Zhou X.H., Zhang L.C., Ying J.F., Zhang Y.T., Wu F.Y., Zhu R.X. Late Mesozoic volcanism in the Great Xing an Range (NE China): timing and implications for the dynamic setting // Earth Planet. Sci. Lett., 2006, v. 251, № 1-2, p. 179-198.

Wasserburg G.J. Isotopic abundances: inferences on solar system and planetary evolution // Earth Planet. Sci. Lett., 1987, v. 86, № 2-4, p. 129-173.

Zhang J.H., Gao S., Ge W.C., Wu F.Y., Yang J.H., Wilde S.A., Ming Li M. Geochronology of the Mesozoic volcanic rocks in the Great Xing'an Range, northeastern China: implications for the subduction-induced delamination // Chem. Geol., 2010, v. 276, № 3-4, p. 144-165. 